San Jose State University

SJSU ScholarWorks

Master's Theses

Master's Theses and Graduate Research

Summer 2021

\title{
Hook-billed Kite, Chondrohierax uncinatus, southbound autumn migration in Belize and Mexico
}

Ryan Anthony Phillips

San Jose State University

Follow this and additional works at: https://scholarworks.sjsu.edu/etd_theses

\section{Recommended Citation}

Phillips, Ryan Anthony, "Hook-billed Kite, Chondrohierax uncinatus, southbound autumn migration in Belize and Mexico" (2021). Master's Theses. 5214.

DOI: https://doi.org/10.31979/etd.qvnc-rk4f

https://scholarworks.sjsu.edu/etd_theses/5214

This Thesis is brought to you for free and open access by the Master's Theses and Graduate Research at SJSU ScholarWorks. It has been accepted for inclusion in Master's Theses by an authorized administrator of SJSU ScholarWorks. For more information, please contact scholarworks@sjsu.edu. 


\section{A Thesis}

Presented to

The Faculty of the Department of Environmental Studies

San José State University

In Partial Fulfillment

of the Requirements for the Degree

Master of Science

by

Ryan A. Phillips

August 2021 
(C) 2021

Ryan A. Phillips

ALL RIGHTS RESERVED 
The Designated Thesis Committee Approves the Thesis Titled

HOOK-BILLED KITE, CHONDROHIERAX UNCINATUS, SOUTHBOUND AUTUMN MIGRATION IN BELIZE AND MEXICO

by

Ryan A. Phillips

APPROVED FOR THE DEPARTMENT OF ENVIRONMENTAL STUDIES

SAN JOSÉ STATE UNIVERSITY

August 2021

Lynne A. Trulio, Ph.D.

Department of Environmental Studies

Scott A. Shaffer, Ph.D.

Department of Biological Sciences

Ronald Melcer Jr., Ph.D.

Senior Environmental Scientist,

Candidate

California State Parks 


\title{
ABSTRACT \\ HOOK-BILLED KITE, CHONDROHIERAX UNCINATUS, SOUTHBOUND AUTUMN MIGRATION IN BELIZE AND MEXICO
}

\author{
by Ryan A. Phillips
}

The Hook-billed Kite (Chondrohierax uncinatus) is a specialized Neotropical raptor with a wide distribution that has received little research attention. The species is considered non-migratory across most of its distribution, but there are scattered records of Hook-billed Kite migration. The present research describes, for the first time, the largest southbound autumn migration of Hook-billed Kite in Belize and Mexico and evaluates the effects of environmental conditions on this phenomenon. Eight years of count data were collected in Belize and 25 years in Mexico. During a total of 3093.1 count hr from 2013-2020 in Belize, 39928 Hook-billed Kites were counted on their southbound autumn migration with a mean $( \pm \mathrm{SE})$ annual count of $4991 \pm 1083 \mathrm{kites} / \mathrm{yr}$. In comparison, during a total of 42531 count hr from 1995-2019 at two count sites in Mexico, 3870 Hook-billed Kites were counted. The mean $95 \%$ seasonal passage window of Hook-billed Kites in Belize was $44.9 \pm 2.5$ d $(n=8)$ from 26 October to 9 December compared to 13 September to 11 November in Mexico. Precipitation on the breeding grounds had no influence on the timing or magnitude of the kite migration through Belize, whereas in Mexico, migration time occurred later as precipitation north of the count site increased. The present research provides critical ecological information, which can aid in identifying potential threats, conservation needs, and population status for Hook-billed Kites and other Neotropical raptors. 


\section{ACKNOWLEDGMENTS}

I would like to first thank and acknowledge my family for their tremendous support through graduate school and beyond. Thank you to my parents for getting me into nature at an early age and instilling in me the values of the environment, as well as their continued support of all my endeavors. I would also like to give a special thank you to my wife Wendy, and my daughter Farrah. While I worked full time on multiple jobs and projects, and raising our daughter, Wendy supported me through Graduate School with often long nights and long days working on my thesis and course load. I know it was not easy, but we did it! Farrah seeing me work on my graduate work hopefully helped instill in her the importance of education. I would like to thank my sister, Samara, brother-inlaw, Josh, and brother, Cody, for always being there for me and supporting what I do. I would also like to thank my mother-in-law, Joyce Williams, for her support. A special thank you goes to one of my biggest fans, my grandma Joy ('Bruno'), who always loved to hear of my accomplishments. I wish you could have seen me defend my thesis, but I know you would have been proud.

Thank you to all of you I have met along my journey in the conservation and environmental field that I have learned from and become inspired by. You know who you are. One person that was a hero of mine that I want to acknowledge, was the eco-warrior Sharon Matola, who sadly passed away this year. She taught me so much about conservation and the interaction of humans and animals. I recall when she told me that conservation is working with people not animals. So true, I understand that now! 
I would like to thank my committee Drs. Lynne Trulio, Scott Shaffer, and Ron Melcer for their support and advice through this process. Dr. Trulio accepted me into this program with open arms. I appreciate Ron pushing me with bird theory and statistical analysis every step of the way and knowing I could pick up the phone any time to discuss it. Thanks to all of them for reaching one of my life goals of obtaining a graduate degree.

This research would not have been possible without the many staff, volunteers, and donors. I would like to thank my Hawk Watch Day Leaders that tirelessly assisted with collecting the Belize Hawk Watch data day in and day out. They included Victor Bonilla, Eduardo Ruano, Jonathan Urbina, Victor Gamez, Isael Mai, Philip Balderamos, Liberato Pop, and Isaias Morataya. Thanks to Roni Martinez for assisting with and supervising the count. Their dedication contributed greatly to the success of the Belize Hawk Watch, a community-based research and conservation project. Thank you to all the great interns and volunteers that counted raptors with us, with a special thank you to Reymundo Chen and Matthew Sacul for their dedication and assistance counting raptors. Without the financial and continued support from Rebecca Harvey, Diane and Tom Bennett, Richard Kuehn and Dean Schuler, Kristin Jenson-Sullivan and Mark Sullivan, Bob Power, and Katie Brown, the Belize Hawk Watch would not have been possible. Thank you to Beth and Tom Hamel, and Brian Sullivan for the kind donations of camera equipment to help document this migration. Thank you to Wil Maheia and the Toledo Institute for Development and the Environment for their local support in Belize. And thanks to everyone that purchased a Hawk Watch fundraising shirt or contributed to the project. 
Many people advised and helped me along the way during this research. They included Jack Clinton-Eitniear on his support of my pursuit of Neotropical research and conservation, Ryan Bourbour and Breanna Martinico on helpful edits, advice and support, Dr. John Abatzoglou on the TerraClimate dataset, Dan Dourson and Dr. Bram Breure for the dialogue and advice on snail ecology, and Sean Gee for advice on statistical analysis. I greatly appreciate Kashmir Wolf and Pronatura Veracruz, A. C. for allowing me permission to use the Veracruz Hook-billed Kite data and for their dedication to raptor research and conservation. Lastly, thanks to Hawk Migration Association of North America for their support and interest in this research.

This is dedicated to my daughter, Farrah, who inspires me every day to continue to fight for a bright future for her and an environmentally healthy planet. 


\section{TABLE OF CONTENTS}

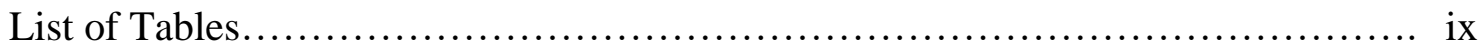

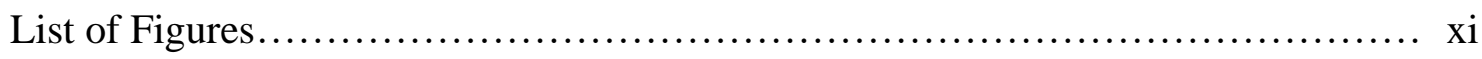

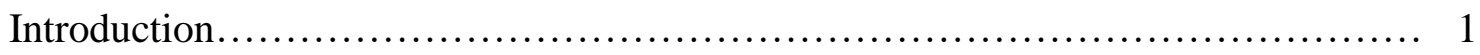

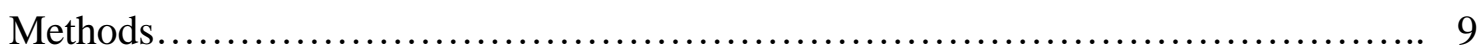

Study Region..................................................... 9

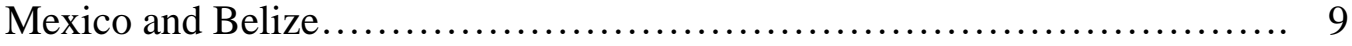

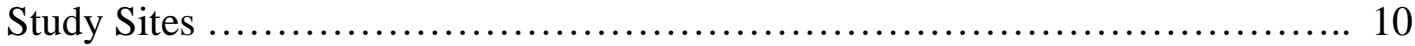

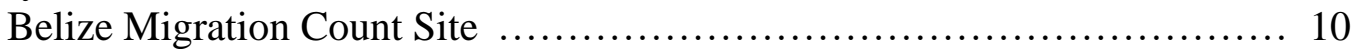

Mexico Migration Count Site ........................................ 12

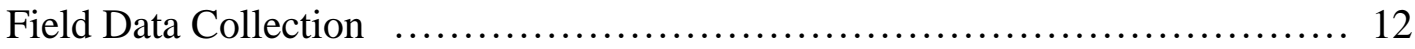

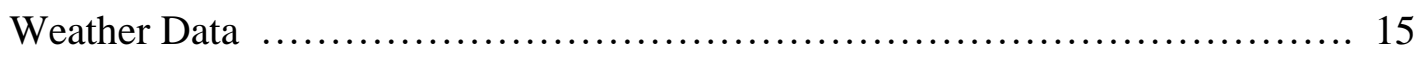

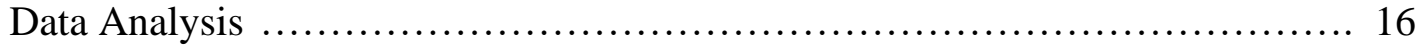

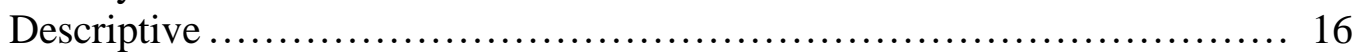

Statistical...................................................... 18

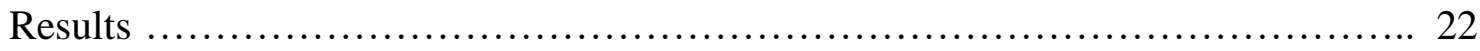

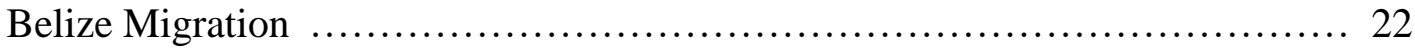

Mexico Migration....................................................... 29

Influence of Weather .............................................. 32

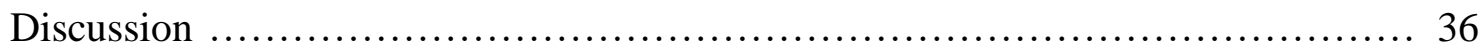

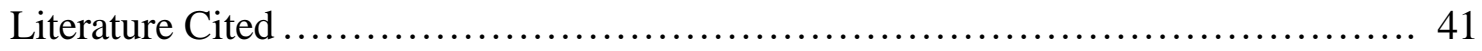




\section{LIST OF TABLES}

Table 1. Predictor and response variables, time frame factors, and regional factors used to analyze how weather influenced the Hook-billed Kite migration in Belize and Mexico

Table 2. Seasonal passage timing of the Hook-billed Kite migration at the Belize count site in Cattle Landing, Toledo District, Belize from 2013-2020.....

Table 3. Annual Hook-billed Kite flock size and number of southbound migrating flocks observed at the Belize migration monitoring site in Cattle Landing, Toledo District from 2014-2020 (7 years)

Table 4. The proportion of morph type of migratory Hook-billed Kites and the total number of kites identified to morph and counted in Belize from 2014-2020

Table 5. Comparison of Hook-billed Kite autumn migration totals for Belize and Mexico count sites during overlapping years (2013-2020)

Table 6. Model selection evaluating the effects of precipitation on the breeding grounds north of the Belize count site on the number of Hook-billed Kites that migrate south during fall migration during various time periods (annual total rainfall, breeding season total rainfall, prior month total rainfall and prior year total rainfall) and geographic locations (Mexico Gulf Plain, Yucatán Peninsula, and Guatemala and Belize) from 20132019. The response variable is the number of kites per hour in a count season

Table 7. Model selection evaluating the effects of precipitation on the breeding grounds north of the Belize count site on the timing of Hook-billed Kites that migrate south during fall migration during various time periods (annual total rainfall, breeding season total rainfall, prior month total rainfall and prior year total rainfall) and geographic locations (Mexico Gulf Plain, Yucatán Peninsula, and Guatemala and Belize) from 2013-2019. The response variable is the Julian day of the median passage $(50 \%)$ in a count season

Table 8. Model selection evaluating the effects of precipitation and temperature on the breeding grounds north of the Mexico count sites on the number of Hook-billed Kites that migrate south during fall migration during various time periods (annual: January-December, breeding season: May-August, prior month: August, and prior year (January-December) from 1995-2019. The response variable is the number of kites per hour in a count season..... 34

Table 9. Model selection evaluating the effects of precipitation and temperature on the breeding grounds north of the Mexico count sites on the timing of Hook-billed Kites that migrate south during fall migration during various 
time periods (annual: January-December, breeding season: May-August, prior month: August, and prior year (January-December) from 1995-2019. The response variable is the Julian day of the median passage (50\%) in a count season 


\section{LIST OF FIGURES}

Figure 1. The study area including count site locations, weather grids(dots represent the center of a $4 \times 4 \mathrm{~km}$ grid), and regional factor areas

Figure 2. An increasing count trend from 2013-2020 of the Hook-billed Kite autumn migration in Belize

Figure 3. Daily passage activity times of the Hook-billed Kites during fall migration at the Belize migration monitoring site from 2014-2020 (7 yr, $n=34271$ kites)

Figure 4. Southbound migrating Hook-billed Kites in Belize. (A) A large kettle on 11 November 2018. (B) Adult light morph female. (C) A flock streaming in a southern direction over count site. (D) Adult light morph male. (E) Adult dark morph. (F) Juvenile light morph ... 26

Figure 5. Comparison of the timing (mean; $n=6 \mathrm{yr}$ ) and proportions (individuals of class/total individuals of all class identified) of age and sex classes by migratory Hook-billed Kites in Belize from 2015-2020 28

Figure 6. Comparing the Hook-billed Kite timing (day of year) of the southbound migration in Belize (2013-2020) and Mexico (1995-2019)

Figure 7. Population trend from 1995-2019 (25 yr) of the Mexico Hook-billed Kite fall migration. Pooled counts from the two Mexico count sites 


\section{INTRODUCTION}

The most biodiverse raptor communities can be found in the Neotropics, which ranges from Mexico through tropical and temperate South America, encompassing approximately one third of all raptor species globally (Bildstein 2004). Despite having high species richness, relatively little research has focused on raptors in this region, creating critical information gaps in our understanding of the ecology and ecological needs of these species (Whitacre 2012, Buechley et al. 2019). Tropical raptors are integral components in maintaining intact tropical ecosystems (Sergio et al. 2008, Estes et al. 2011), but they are declining globally and locally due to anthropogenic factors, such as habitat loss and persecution, and to an unknown extent, climate change (Carrete et al. 2009, McClure et al. 2018). To better assess, conserve, and protect raptors in the Neotropics, ecological information gaps need to be bridged to assist in protecting raptors in tropical ecosystems and maintaining healthy intact ecosystems for all species (Farmer and Smith 2010, Buechley et al. 2019).

Currently, there are major information gaps in our understanding of the migration and movement ecology of Neotropical raptor species (Buechley et al. 2019). Migration is a critical component of the annual cycle for many avian species (Newton 2008, Dingle 2014), particularly raptors, and allows for survival by adapting to adverse environmental conditions, foraging strategies, and reproduction (Miller et al. 2016, Henrique and Grant 2019). Movement plays an important role in population regulation, population and community dynamics, and the survival of species (Henrique and Grant 2019). Studying movement and migration of tropical raptors is critical to better understand how species 
are impacted and potentially threatened by anthropogenic activities and changing environmental conditions to assist with their conservation efforts (Chapman et al. 2011).

Monitoring raptor species using migration counts has been a viable and important conservation tool since the late nineteenth century (Bildstein 2006, Bildstein et al. 2007). Because raptors are generally secretive, wide-ranging, highly mobile, and occurring at low abundance, they are logistically challenging to survey and monitor (Zalles and Bildstein 2000, Bildstein et al. 2007). However, with the establishment of hundreds of raptor migration count sites globally, this method of counting migrating raptors when they are most abundant, visible, and concentrated has become critically important for monitoring raptor population trends and phenology (Zalles and Bildstein 2000, Hoffman and Smith 2003).

Raptor migration count sites in the Neotropic region have focused primarily on longdistance migrations of Nearctic-Neotropical migrants, which are species or populations that breed in North America and regularly migrate south into Central and South America during the non-breeding season (Hayes 1995). Examples of these types of species include the Broad-winged Hawk (Buteo platypterus), Swainson's Hawk (Buteo swainsoni), and Mississippi Kite (Ictinia mississippiensis) (Bildstein 2004). Little focus has been on Intratropical migrants, species that breed in the tropics and annually migrate to another area of the tropics, such as the Plumbeous Kite (Ictinia plumbea) (Hayes 1995, Zalles and Bilstein 2000, Bildstein 2004, Whitacre 2012). The Plumbeous Kite arrives on its breeding grounds in Guatemala, Belize and southern Mexico, the northern extent of its range, late February to early March and departs southbound post-breeding in August 
(Seavy et al. 2012). In the northern extent of the Neotropics, kites are the only known raptors to be migratory (Whitacre 2012). Thus, Nearctic-Neotropical monitoring programs have different study objectives, and do not specifically capture the movements of these species that breed and winter in the Neotropical region, such as these kites.

The migration and movement patterns of Neotropical raptors have not been studied and information on their movements is limited, making this group a high research priority to help elucidate these enigmatic movement patterns (Bildstein 2004, Buechley et al. 2019). The Hook-billed Kite (Chondrohierax uncinatus) is an example of a Neotropical species that is migratory where its migration had not been studied and described. The Hook-billed Kite is primarily a Neotropical raptor species with a range from extreme southern Texas to northern Argentina. Despite this wide distribution, the Hook-billed Kite is generally uncommon to rare locally, with local declines observed (Ferguson-Lees and Christie 2001, Colorado et al. 2006, Johnson et al. 2007). Having an exclusive diet of arboreal snails make the Hook-billed Kite a unique and specialized Neotropical raptor. They are found in a variety of forest types, which include, but are not limited to, tropical lowland evergreen forest, tropical deciduous forest, gallery forest, montane evergreen forest, and xeric woodland (Ferguson-Lees and Christie 2001, Whitacre and Vásquez 2012, Clark and Schmitt 2017). However, they are believed to occupy these habitats only where high densities of land snails occur, as prey is considered the primary driver in their presence, which is likely why they are not common outside of the migration in Belize described here (Smith 1988, Clark and Schmitt 2017). 
The breeding ecology of Hook-billed Kites has been little studied but appears to be complex and unique among raptors (Phillips et al. in review). Hook-billed Kite nests have been documented in Texas (Fleetwood and Hamilton 1967, Delnicki 1978, Webster 1978, Clark 2002, Clark 2003, Clark 2004, Brush 2005), Mexico (Smith 1982, Rowley 1984), Guatemala (Marroquin et al. 1992, Whitacre and Vásquez 2012), Belize (Phillips et al. in review), Costa Rica (Orians and Paulson 1969), Grenada (Smith and Temple 1982, Thorstrom et al. 2001, Thorstrom and McQueen 2008), Suriname (Haverschmidt 1964, Haverschmidt 1968), Brazil (Krügel 2003), and Argentina (Di Giacomo 2000). The Hook-billed Kite nesting season occurs from mid-March through mid-October throughout its range (Whitacre and Vásquez 2012, Phillips et al. in review). In Belize, a pair was observed to have three successful broods in a single nesting season and nesting occurs into October making this the longest and latest breeding season of any Neotropical raptor, to our knowledge (Phillips et al. in review). It appears that the nesting season is synchronized closely with the onset of the wet season or during the wettest months (Haverschmidt 1964, Marroquin et al. 1992). Therefore, precipitation may influence the abundance and availability of the Hook-billed Kite prey, reproductive success, and movement patterns.

Hook-billed Kite movement behavior has been described in a variety of ways. It is currently classified as an irruptive or local migrant (Zalles and Bildstein 2000, Bildstein 2004) with migratory movements observed in Mexico (Ruelas et al. 2010, Whitacre and Vásquez 2012), Belize (Jones 2002, Phillips et al. 2015), Costa Rica (Tenorio et al. 2020) and northern South America (Venezuela, French Guyana, Brazil; de Melo Dantas et al. 
2018). Bildstein (2004) characterized irruptive or local migrant species as having a small latitudinally-peripheral migratory or partially migratory population. Newton (2006) describes an irruptive species as a species that exploits sporadic resources that shows flexibility in their movement patterns, concentrating in different areas in different years, wherever resources are plentiful at the time. However, the Hook-billed Kite has also been described as a non-migratory and resident species (Stiles and Skutch 1989, FergusonLees and Christie 2001, Birdlife International 2020), even though they exhibit conspicuous annual southbound autumn movements that have been observed in Mexico and Belize.

The various descriptions of migratory behavior for Hook-billed Kites are complex and mysterious. However, plasticity occurs in migration among populations where different individuals of the same species can exhibit different migratory patterns (Chapman et al. 2011). This can result in contradictory descriptions of a species migratory behaviors. Migration is a complex ecological phenomenon that varies between species, populations, and individuals (Newton 2008, Boyle 2011, Chapman et al. 2011, DeSimone et al. 2021). Most migratory species that move between breeding and nonbreeding areas exhibit a partial migration where some individuals move away from their breeding areas, while others do not (Boyle 2011). The movements of facultative partial migrant species, also known as irruptive, have been found to be associated with interannual fluctuating environmental conditions that influence availability of food supply, resulting in sporadic or unpredictable movements (Zalles and Bildstein 2000, Newton 2006, Boyle 2011, Newton 2012, DeSimone et al. 2021). Therefore, migration is 
optional, where individuals may migrate in some years but not in others due to unpredictability of prey abundance or weather conditions (Boyle 2011, Newton 2012).

In contrast, obligate migrants are programmed to migrate generally at the same time, direction, and distance each year with little deviation (Newton 2012). It is not completely understood if this a facultative or obligate migratory population of Hook-billed Kites in the northern extent of its large distribution, but it is a partial migration as Hook-billed Kites are observed throughout their range during all months (Sullivan et al. 2009).

Populations of the Hook-billed Kite were first documented as showing an annual migratory pattern in the early 1990s in Mexico at the two Veracruz, Mexico migration monitoring sites, which were shown to average fewer than 200 individuals annually during the autumn migration (Ruelas et al. 2010, Whitacre and Vásquez 2012). Jones (2002) documented the first migratory movements of Hook-billed Kites in 1999 in Belize along the southern coast in the Toledo District. In subsequent years, Jones conducted scattered daily counts and estimated that 5000 Hook-billed Kites migrated south through Belize annually in autumn (Jones 2002, Whitacre and Vásquez 2012, Jones pers. comm.). He concluded that Hook-billed Kites were the most common migrating raptor through Belize (Jones 2002). This magnitude is exceptional compared to all other observations of migrating Hook-billed Kites. For example, in northeastern South America, observations of flocks are rare and do not occur annually; the largest flock recorded was 35 individuals (de Melo Dantas et al. 2018). Tenorio et al. (2020) observed 16 migrating Hook-billed Kites in Costa Rica for the first time, with the largest group comprised of nine individuals. This range of observations highlights our limited understanding of the 
species' movement and migration ecology, especially for the Hook-billed Kite populations in Mexico and Central America.

In 1991, Ruelas et al. (2010) founded the Veracruz River of Raptors Project, the first raptor migration monitoring site in Mexico to better understand the raptor migration through this geographical bottleneck, which was found to have the greatest magnitude of migrating raptors globally (Zalles and Bildstein 2000, Ruelas 2005). Counts during the autumn southbound migration commenced in 1992 and have occurred annually since (Ruelas 2005). However, in Belize there were not any extensive or systematic counts conducted prior to this study with the only observations of this migration made by Jones (2002, pers. comm.). Therefore, in 2013, the Belize Raptor Research Institute, now the Belize Bird Conservancy, initiated the first raptor migration monitoring site in the Toledo District in southern Belize to collect annual systematic count data on the magnitude and phenology of the southbound autumn migration of Hook-billed Kites and other raptors for the first time. The availability of long-term count data from Mexico and Belize affords a rare opportunity to study how weather conditions on the breeding grounds influence the post-breeding migration of Hook-billed Kites in Belize and Mexico.

Given the uncertainty in migration behavior in this species, I sought to characterize movement patterns. Hence, the objectives of this research were to provide the first comprehensive description of the migration pattern of Hook-billed Kites, and to investigate how environmental factors may influence the magnitude and timing of Hookbilled Kite migration at the northern extent of their distribution using data from three raptor migration monitoring sites in Belize and Mexico. Specific research objectives 
included: 1) characterizing the timing and magnitude of Hook-billed Kite post-breeding migration during the southbound autumn migration in Belize and Mexico, 2) determining the population demographics (sex, age, and morph) and whether there was a differential migration at the Belize count site, and 3) evaluating if environmental conditions on the breeding grounds influenced the timing and magnitude of Hook-billed migration in Belize and Mexico. I hypothesized that precipitation and/or temperature would have an influence on magnitude and timing of Hook-billed Kite and that the greatest influence would be in the Yucatán Peninsula in Mexico with fewer kites migrating south in years with less precipitation.

This research provides novel information on the movement ecology of a migratory population of Hook-billed Kites, how weather conditions influence this migration, and population trends. It is also the first migration study conducted, specifically on a Neotropical migratory raptor. This critical ecological information, in light of humancaused climate change and habitat loss, will aid in identifying potential threats, conservation needs, and population status for Hook-billed Kites and other Neotropical raptors. 


\section{METHODS}

\section{Study Region}

\section{Mexico and Belize}

The regional weather data were collected north of the Belize count site throughout the Hook-billed Kite's distribution where this migratory population breeds prior to migrating south during autumn migration (Fig. 1). The majority of the breeding range includes the eastern Coastal Plain and foothills of Mexico into extreme southern Texas, Yucatán Peninsula in Mexico, Petén in northern Guatemala, and all of Belize.

The climate of this region is highly variable, particularly in Mexico (Kottek et al. 2006). The Tropic of Cancer $\left(23.5^{\circ} \mathrm{N}\right)$, which bisects Mexico, is the dividing line between the tropical and temperate climatic zones. The Köppen-Geiger climate classification systems for the region where Hook-billed Kites occur in Mexico include equatorial monsoon, equatorial savannah with dry winter, steppe, equatorial savannah with dry season, equatorial rainforest fully humid, and warm temperature fully humid (Kottek et al. 2006). The Hook-billed Kite's northern extreme distribution is $c .300 \mathrm{~km}$ north of the Tropic of Cancer. This area and south along the Gulf Coast Plain has an annual mean temperature between $24-28^{\circ} \mathrm{C}$, and temperatures fluctuate little, $5^{\circ} \mathrm{C}$, between the summer and winter months (Howell and Webb 1995, Parkes et al. 2021). Rainfall varies greatly by location and season, but is the greatest in the southeastern region, which includes Yucatán, Tabasco, Chiapas, and Veracruz provinces, and the central and southern Pacific Coast (Howell and Webb 1995, Rhoda and Burton 2010). Areas with higher precipitation receive a mean annual precipitation of $100-200 \mathrm{~cm}$ 
(Howell and Webb 1995, Parkes et al. 2021). Seasons are separated into a dry (FebruaryMay) and wet season (June-November) (Howell and Webb 1995).

The study area is in the hurricane belt and is susceptible to major storms from JuneNovember, a significant factor in the variability of weather patterns (Young 2008). The Gulf of Mexico and the Caribbean Coast, where the majority of breeding Hook-billed Kites occur, experiences larger and more frequent hurricanes than the Pacific Coast due to warmer waters and a northwest movement (Parkes et al. 2021).

\section{Study Sites}

\section{Belize Migration Count Site}

The Hook-billed Kite migration count data in Belize were collected from a single site located on a soccer pitch with open viewing in all directions in Cattle Landing of the Toledo District of Belize, Central America. The count site was surrounded by lowland broadleaved forest and is $15 \mathrm{~m}$ from the coastline of the Caribbean Sea, which is $c .7$ masl. The count site was located at $16.120219 \mathrm{~N}$ and $-88.794308 \mathrm{~W}$, which is $c .2 .5 \mathrm{~km}$ north of Punta Gorda, Belize (Fig. 1).

This count site location was selected for these features: 1) the location with the largest known concentration of migrating Hook-billed Kites (Jones 2002); 2) close proximity to the coastline, which south-bound migrating raptors use as a guide to limit their overocean movement and reduce energy costs; 3 ) the geographic location in accordance to what is known about raptor migration throughout the region based on previous research; 4) expansive open area with a full 360 degree view amidst broad-leaved forest where soaring raptors can be seen up to a distance of $5 \mathrm{~km}$; and 5) its proximity to a local 
community, making it easier for locals to participate in the count and making educational outreach efforts more effective.

Belize has a subtropical climate with two seasons, dry (February-May) and wet (JuneNovember). Two months (December-January) are considered transitional, falling in neither the dry nor wet season, but are colder than other months (Hartshorn et al. 1984, National Meteorological Service of Belize 2021). The temperature and precipitation vary throughout Belize depending on the effects of the northeast trade winds off the Caribbean Coast, as well as elevation and proximity to the coast (National Meteorological Service of Belize 2021). Variation in Belize precipitation creates unique climatic zones, which are classified as equatorial monsoon and equatorial savannah with dry winters according to the Köppen-Geiger classification system (Kottek et al. 2006). In northern and western Belize, average annual rainfall was approximately $100 \mathrm{~cm}$ (Hartshorn et al. 1984). In the south, where the Belize count site was located, rainfall averages approximately $450 \mathrm{~cm}$ (Hartshorn et al. 1984). The habitat was categorized as lowland broad-leaved forest (Meerman and Sabido 2001). The wet season is longer in the southeast extreme of Belize, from May through January (Hartshorn et al. 1984, National Meteorological Service of Belize 2021) with most rain occurring at night. The mean temperature varies from $27^{\circ} \mathrm{C}$ along the coast to $21^{\circ} \mathrm{C}$ in the mountains (National Meteorological Service of Belize 2021). The coldest month is January and the warmest is May (National Meteorological Service of Belize 2021). The average monthly temperature at the count-site is $26.2^{\circ} \mathrm{C}$ (National Meteorological Service of Belize 2021). The average minimum temperature is 
$21.5^{\circ} \mathrm{C}$ and the maximum is $30.8^{\circ} \mathrm{C}$ in Punta Gorda, the nearest major town to the count site (National Meteorological Service of Belize 2021).

\section{Mexico Migration Count Site}

The Hook-billed Kite migration count data in Mexico were collected from two of the longest operating raptor migration monitoring sites in the Neotropics, which is described in detail by Ruelas et al. (2009). One is in Cardel, Veracruz (19.37110 N, -96.37653 W) and the other in Chichicaxtle, Veracruz (19.34308 N, -96.46419 W) (Fig.1). The Cardel count site is in the lowlands of the Gulf Coastal Plain (29 masl) $7 \mathrm{~km}$ from the ocean. The Chichicaxtle count site is located $11 \mathrm{~km}$ directly west of the Cardel site (120 masl). Both are perpendicular to the migration (north-south movement) along an east-west axis. The counts sites were located at the intersection of two major mountain systems that creates a geographic bottleneck with the Gulf of Mexico and the largest concentration of migrating raptors in the world (Zalles and Bildstein 2000).

\section{Field Data Collection}

This research used a non-invasive observational approach to quantitatively describe the Hook-billed Kite migratory population and assess how weather conditions may influence their migration patterns. Eight yr (2013-2020) of count data was collected in Belize. The Mexico count data that was used in this research included $25 \mathrm{yr}$ (1995-2019) from the two count sites. In Belize, the first year of data collection occurred between 15 September and 7 December 2013. In 2014, the count period was changed to 1 October to 15 December due to the late migration of Hook-billed Kites observed in 2013. In 2015, the count period was 15 October to 15 December because Hook-billed Kites did not start 
to migrate until mid-October. However, to include any exceptionally early migrating Hook-billed Kites in Belize, the count period was established from 1 October- 15 December as the standard count period. The count period in Mexico was 20 August- 20 November, as the focus of the Veracruz raptor counts were primarily for Nearctic species (Ruelas et al. 2010).

The count procedure followed a standardized and widely used count protocol created by Hawk Migration Association of North America, described in detail by Bildstein et al. (2007). In Belize, Hook-billed Kites were counted daily from 0800-1600 H (local time) during the duration of the autumn southbound migration. Veracruz count hours were 10 hr count days from 0800- $1800 \mathrm{H}$ local time (Ruelas et al. 2009).

The raptor migration counts in Belize and Mexico were collected by a trained and experienced team of hawk counters. Local community members were the team day leaders, and team members included national and international personnel that were trained prior to the count. Training occurred through in-field and in-class sessions. Training local community members built local capacity in raptor research and conservation, as well as forming a specialized and sustainable team to gather long-term accurate and consistent data on raptor migration in Belize and Mexico. The protocol had a minimum of 3 members present during count hours, but the number of team members above three varied among days. In Belize, the number of team members ranged from 310 individuals and Mexico had a wider variation.

The count teams in Belize included an experienced and skilled day leader, data recorder/s, and spotters or counters (Phillips 2014). The data recorder/s also spotted 
raptors, when not recording, but their primary duty was to transcribe the data into the datasheets and enter it into the Dunkadoo data application. Dunkadoo is an important infield data collection digital application program that was developed to assist bird migration counts and was adopted at the Belize count in 2017 (Dunkadoo 2021). Spotters constantly scanned the sky with their binoculars. When a raptor was seen, the observer informed the other team members so identification could be made by multiple observers. To assist with identification, spotting scopes and various field guides were used at the count site. Most (>95\%) Hook-billed Kites moved in a consistent directional movement, and flocks were watched from first observation to when they passed over the count site and out of sight so that individuals were not double-counted.

A modified version of the quadrant system was adopted for counting raptors in Belize (Fish 1995, Fish 2001). Since nearly all the raptors are generally migrating in a north to south direction over this count site, the count was bisected into east and west sections.

In Belize, three data sheets were used. They included: 1) the Hawk Migration Association of North America Daily Report Form; 2) a sheet with all species sex, age, and morph; and 3) a metadata sheet for Hook-billed Kites (Phillips 2014). Hook-billed Kites are sexually dimorphic, and plumage differs dramatically between juveniles and adults making them identifiable while migrating. With sex, morph, and age being identifiable, this afforded an opportunity to collect data on Hook-billed Kite population structure. Data collected on Hook-billed Kites included date, time, flock size, flock number, sex, age, and morph. Each kite was attempted to be identified to age, sex, and morph, but due to height of flight and distance from the site some individuals could not 
be identified. However, the identified sample is considered a representation of the entire population, even though not all individuals were identified, because flight behaviors did not vary between age, sex, or morph. As well as there was no differentiation in migration timing or flock association by juveniles or adults, males or females, or dark or light morphs.

In Belize, variables that were recorded at the start of each count hour included number of observers, number of visitors, wind speed, wind direction, temperature, barometric pressure, cloud cover, visibility, precipitation, average flight direction, and average height of flight (Phillips 2014). A Kestrel 2500 Weather Meter (Kestrelmeters.com) was used to record wind speed, temperature, and barometric pressure. Flight path direction of travel was determined using a compass. The standard hawk watch scales widely used for precipitation and height of flight scales were adopted (Phillips 2014, Hawk Migration Association of North America 2021). The Mexico counts followed a similar data collection process, which are described in detail in Ruelas (2005).

\section{Weather Data}

I obtained weather data in the breeding range of the Hook-billed Kite north of the count sites from the TerraClimate dataset for 1995-2019 count years (Fig. 1). Weather data north of the count sites were extracted because this was the presumed origin and breeding locations of the migratory Hook-billed Kites, pre-migration, that were counted on their southbound autumn migration.

TerraClimate is a monthly, high-spatial-resolution (4 km grids) weather dataset from 1958-2019 (Abatzoglou et al. 2018). It uses climatically aided interpolation, combining 
high-spatial resolution climatological normals from the WorldClim dataset (Abatzoglou et al. 2018). The spatiotemporal aspects of TerraClimate were validated from weather station data, which showed a noted improvement in error and increased spatial realism relative to other datasets (Abatzoglou et al. 2018). Therefore, this TerraClimate data was adopted for this ecological modeling analysis. The weather (explanatory) variables that were extracted from the dataset were precipitation (monthly total), minimum temperature (monthly mean), and maximum temperature (monthly mean).

Terraclimate weather grids were randomly selected where there were confirmed eBird records (Sullivan et al. 2009) of Hook-billed Kites during the breeding season (MayAugust) to ensure that these were breeding areas. For the Belize count, the sample size was 50 weather grids, of which 20 were in the Mexico Gulf Coast Plain, 10 in the Yucatán Peninsula, and 20 in Petén, Guatemala and Belize (Fig. 1). For the Mexico count, the sample size was 10 weather grids, which were representative of the breeding range north of the count site, since it was smaller and only included the north Gulf Coast Plain.

\section{Data Analysis}

\section{Descriptive}

The Fleiss' Kappa statistic (adaptation of Cohen's kappa for 3 or more raters) was used to test the interrater reliability of the Belize count data because there were multiple day leaders (McHugh 2012); however, this was not conducted in Mexico as I was not involved with the Mexico count and could not coordinate this reliability test. The reliability test in Belize ensured that the data collected were accurate representations of 
the variables measured, which included species, age, gender, and morph. A kappa value lower than 0.60 is considered weak, whereas a value of $0.60-0.79$ is considered moderate, 0.80-0.90 strong, and above 0.90 almost perfect (McHugh 2012). The team scored a 0.95. The value was determined using photos and the day leaders were tested simultaneously. The test was initiated in 2017 and 2018.

The count data were standardized to the annual passage rate (number of kites counted in a count season per total hours counted), which was the response variable for the magnitude of the Hook-billed Kite migration. The response variable for the timing of kite migration was the median Julian day where $50 \%$ of the kites were counted in a single count season.

The seasonal passage window of the Hook-billed Kite migration was described as the period where the central 95\% of individuals passed through the count sites (RodríquezSantana et al. 2004). The $2.5 \%$ tails of the migration were excluded to avoid using outlier observations. However, the full passage window is reported to include all migrating individuals from the first date of the first Hook-billed Kite observed to the last individual. Analyses on the sex, age, and morph class data were conducted for Belize but not Mexico. A Kruskal-Wallis non-parametric rank sum test was used to compare hourly migration rates during the daily passage window in Belize. The median passage was determined to be the date where $50 \%$ of the season's Hook-billed Kite migration had occurred. Using $50 \%$ of the $95 \%$ seasonal passage window did not change our results; therefore, the full passage was used for the median for analytical purposes, but both are reported. Results were presented as mean \pm SE. 


\section{Statistical}

For statistical analysis, $\mathrm{R}$ version 3.6 .3 was used and $P \leq 0.05$ was considered significant (R Core Team 2020). An information theoretic approach was used to determine how weather influenced the movement of Hook-billed Kites on their breeding grounds pre-migration and was analyzed using generalized linear models. A Gaussian distribution was used for Mexico and Belize since the response variables were normally distributed. Normality was tested using the Shapiro-Wilk test (Zar 1999). Data from three count stations were used for analysis. The data from the two Mexico count stations were pooled due to their independence of being perpendicular, distantly separated so no double-counting, the same breeding grounds, and the data timing highly correlated (Ruelas et al. 2009). Therefore, the counts are referred to as Mexico and Belize.

Independent variables were tested for correlation to avoid multicollinearity and model

dredging issues. Variables that were highly or relatively highly correlated $(r>0.5)$ were not included in the same set of candidate models. For each count site and response variable, a set of a priori models were developed based on ecological knowledge and theory (Anderson and Burnham 2002, Lukacs et al. 2007, Burnham et al. 2011). Two response variables (passage rate and migratory timing) and two count sites (Belize and Mexico) were used to build four sets of candidate models to determine the most parsimonious top models (Table 1). 
Table 1. Predictor and response variables, time frame factors, and regional factors used to analyze how weather influenced the Hook-billed Kite migration in Belize and Mexico.

\begin{tabular}{llll} 
Predictor & Response & Time Frame Factors & Region Factors (Site) \\
\hline Precipitation & Magnitude (kites/hr) & Year/Annual (Jan-Dec) & North Gulf Coast Plain (MX) \\
Temperature & Timing (median) & Year Prior (Jan-Dec) & Gulf Coast Plain (BZ) \\
& & Breeding Season (May-Aug) & Yucatán (BZ) \\
& & Month Prior (Aug/Sep)* & Guatemala/Belize (BZ)
\end{tabular}

*For Belize, September was the month prior to the initiation of migration and August for Mexico

For the weather variables, I analyzed four time frames and three regional factors to determine if weather patterns during a specific time of year and in a specific location influenced the Hook-billed Kite migration (Table 1). The time frames for weather data included 1) full annual cycle (January-December of the count year), 2) breeding season (May- August), 3) one month prior to the onset of migration (September for Belize and August for Mexico), and 4) the prior year (January-December of the prior year of the count). These windows were evaluated to determine if precipitation during a specific time triggered individuals to migrate and influenced the timing and or magnitude of migration. To potentially delineate the breeding origins and regional environmental triggers of the migratory kites counted in Belize, three regional factors were included in the analysis (Fig. 1). They included: 1) the most northerly region, the Mexico Gulf Coast Plain, 2) the Yucatán Peninsula, and 3) Petén, Guatemala, and Belize, north of the count site. The regional factors were used for Belize because the specific breeding region is not known. For Mexico, the breeding grounds north of the Mexico count is a small area and only 
includes the north Gulf Coast Plain; thus, only one region needed to be included in the analysis for Mexico as the general breeding locations are known.

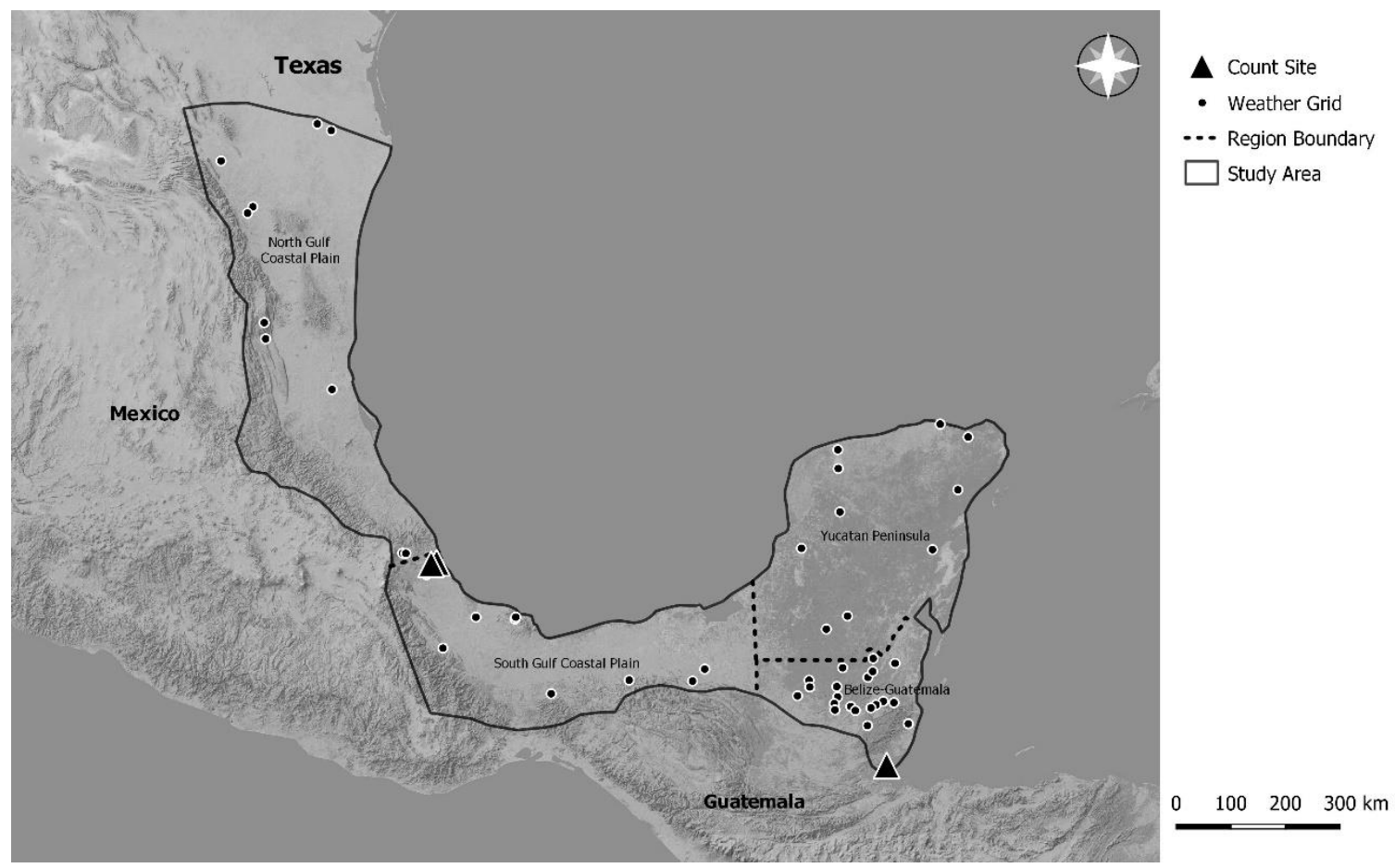

Figure 1 . The study area including count site locations, weather grids (dots represent the center of a $4 \times 4 \mathrm{~km}$ grid), and regional factor areas.

The predictor variables analyzed included precipitation for Belize and precipitation and temperature for Mexico. Temperature as a predictor for Belize was omitted to reduce model dredging due to the high number of variables (Anderson and Burnham 2002) from the regional factors, and because it was determined that precipitation was the more ecologically important variable and greater variation than temperature in the region $(\mathrm{Li}$ and Meng 2017). Land snails, the prey of the Hook-billed Kite, are moisture dependent and influenced by precipitation more so than temperature, which may influence the Hook-billed Kite movement (Barrientos 2000, Perez et al. 2021). Due to the lack of 
variation in monthly minimum and maximum temperatures, the difference between the maximum and minimum was used as the temperature variable for the Mexico candidate models. The monthly precipitation totals were accumulated for each time window resulting in the total precipitation for that time frame.

All sets of models were ranked using Akaike Information Criteria (AIC; Akaike 1973), adjusted for small sample size ( $\left.\mathrm{AIC}_{c}\right)$ to select the most parsimonious models (Anderson and Burnham 2002), which was achieved by evaluating $\mathrm{AIC}_{c}$ values and Akaike weights $\left(w_{i}\right)$ in the R package MuMIn (Bartoń 2019). A sample was considered small if it had <40 samples (Burnham and Anderson 2002). A confidence set of models was created for each set with a delta $\mathrm{AIC}_{c}<2$ of the best fitting models (Burnham and Anderson 2002). 


\section{RESULTS}

\section{Belize Migration}

During a total of 3093.1 hourly counts (536 d) over 8 years (2013-2020) in Belize, 39928 Hook-billed Kites (12.9 individuals/hr) were counted on their southbound autumn migration. The mean $( \pm$ SE) annual count of Hook-billed Kites in Belize was $4991 \pm 1083$ kites/yr ( $n=8 \mathrm{yr})$. The highest annual count was 9755 kites in 2020 during $405.6 \mathrm{hr}$, which equates to $24.1 \mathrm{kites} / \mathrm{hr}$, while the lowest annual count was 744 in 2013 during $510.5 \mathrm{hr}$, which equates to $1.5 \mathrm{kites} / \mathrm{hr}$. A significant positive trend in Hook-billed Kite numbers was observed in Belize from 2013-2020 $\left(F_{1,6}=16.45, r^{2}=0.73, P=0.007\right)$; Fig. 2). The single day high count over 8 yr in Belize was 1610 on 7 November 2020 (Table 2), followed by the second largest single day count on 8 November 2020 of 1441 . These two dates followed many consecutive days of rain across Belize starting from 12 October followed by Hurricane Eta on 3-6 November, which grounded Hook-billed Kites during the first big pulse of migration. The next three largest single day counts were 1101 on 11 November 2018, 981 on 11 November 2019, and 921 on 19 November 2018. The mean peak day was 11 November $(n=8)$ with a mean $( \pm$ SE) of $378.6 \pm 157.2$ kites. 


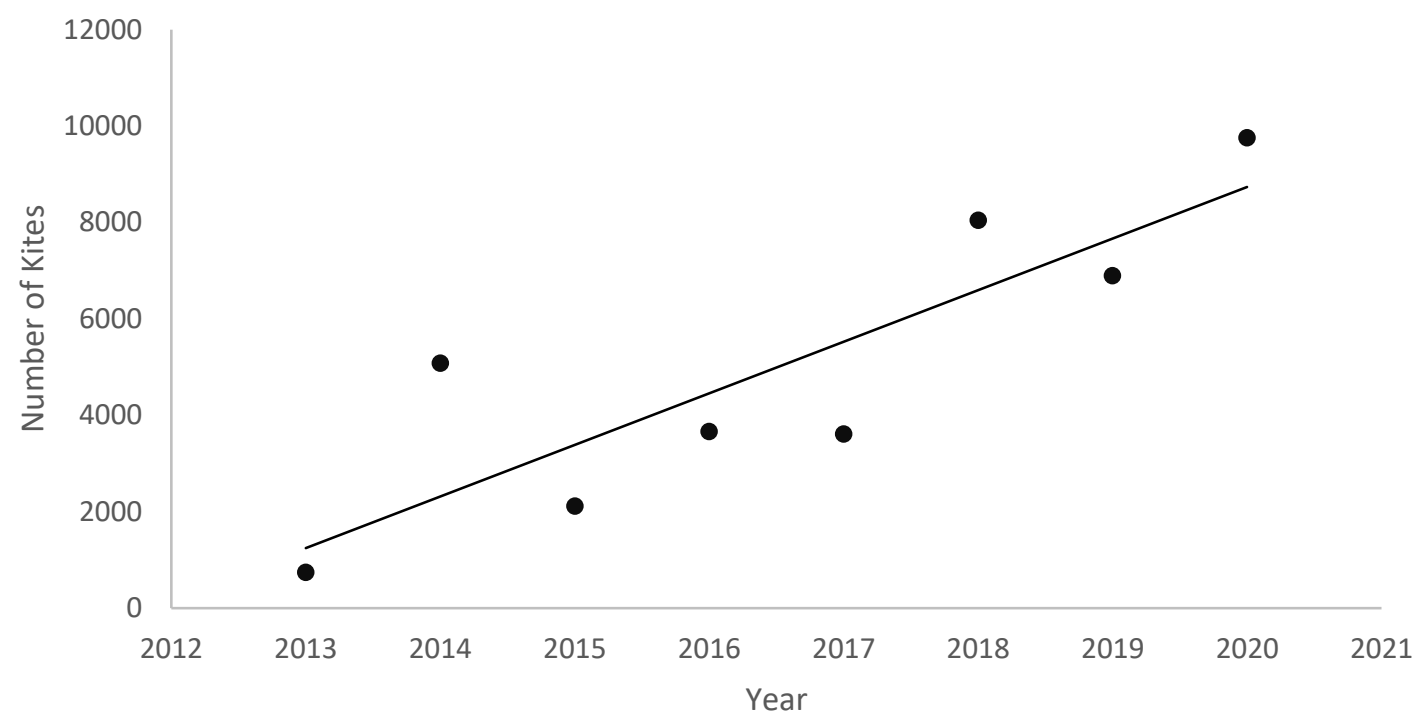

Figure 2. An increasing count trend from 2013-2020 of the Hook-billed Kite autumn migration in Belize.

Table 2. Seasonal passage timing of the Hook-billed Kite migration at the Belize count site in Cattle Landing, Toledo District, Belize from 2013-2020.

\begin{tabular}{|c|c|c|c|c|}
\hline \multirow{2}{*}{$\begin{aligned} \text { YEAR } \\
2013\end{aligned}$} & \multirow{2}{*}{$\begin{array}{l}\text { 95\% PASSAGE (D) } \\
3 \text { November-2 December (30) }\end{array}$} & OTAL DAYS* & \multirow{2}{*}{$\begin{array}{l}\text { MEDIAN }(50 \%) \\
25 \text { November }\end{array}$} & \multirow{2}{*}{$\begin{array}{c}\text { DAILY } \\
\text { HIGH (COUNT) } \\
25 \text { November (143) }\end{array}$} \\
\hline & & 54 & & \\
\hline 2014 & 23 October-13 December (52) & 71 & 10 November & 26 October (479) \\
\hline 2015 & 22 October-10 December (45) & 58 & 26 November & 25 November (377) \\
\hline 2016 & 26 October-11 December (47) & 73 & 15 November & 21 November (412) \\
\hline 2017 & 27 October-12 December (47) & 68 & 15 November & 11 November (366) \\
\hline 2018 & 24 October-14 December (52) & 76 & 11 November & 11 November (1101) \\
\hline 2019 & 28 October-8 December (42) & 75 & 11 November & 11 November (981) \\
\hline 2020 & 26 October-8 December (44) & 71 & 10 November & 7 November (1610) \\
\hline Mean & 26 October-9 December (45) & 68 & 15 November & 13 November (684) \\
\hline
\end{tabular}

*Total days is the total passage window where all migrating Hook-billed Kites are included.

The mean $95 \%$ seasonal passage window of Hook-billed Kites that passed over the Belize count site was $44.9 \mathrm{~d} \pm 2.5(n=8)$ from 26 October to 9 December (Table 2). The mean full passage window (total days of kites observed over the season) in which kites 
were migrating through Belize was $68.3 \mathrm{~d} \pm 2.8$ and the mean $50 \%$ passage (median) was 15 November $(n=8)$. Table 2 displays the variation in timing (phenology) between years. The earliest migrating Hook-billed Kite in Belize was recorded on 1 October and the latest on 15 December.

Hook-billed Kites in Belize did not migrate in equal numbers throughout the daily passage window $\left(X^{2}=34.4, \mathrm{df}=7, P<0.001\right)$. They were observed in all count hours $(0800-1600 \mathrm{H})$, but $63.5 \%$ of kites passed between $900-1200 \mathrm{H}$ and the peak $(23.7 \%$ of all kites counted) was from 1000-1100 H (7 yr, $n=34271$ kites). Following $1100 \mathrm{H}$, activity slowed throughout the day (Fig. 3). Migration was primarily in a northeast to southwest direction during all years (2013-2020) with some deviation as flocks on occasion would circle back north or move west as they appeared to be searching for thermals or wind currents before continuing in the usual direction. Movement was primarily directly over or within $500 \mathrm{~m}$ of the count site and often kites would move through the base of cumulus clouds estimated to be between $c$. 1000- $2000 \mathrm{~m}$. The height of flight varied throughout the day. Typically, during the morning hours kites were low flying (c. 50-300 $\mathrm{m}$ above the ground) and the height of flight increased throughout the day where birds were difficult to spot, even with the aid of binoculars. Migrating kites were either soaring with little flapping-flight in a thermal (kettling; Fig. 4A) or in a glide with occasional flapping (streaming; Fig. 4C). Migrating Hook-billed Kites in Belize were observed as single individuals or in flocks as large as 217 individuals. The largest flock of 217 was observed on 12 November 2020. During 7 yr (2014-2020) there were 8 flocks that were over 100 kites: 150 on 19 November 2018, 136 on 2 November 2019, 
110 on 8 November 2020, 106 on 24 November 2020, 105 on 19 November 2018, 100 on 11 November 2018, and 100 on 19 November 2018. The mean ( \pm SE) flock size was 7.6 individuals $\pm 0.4(n=4490)$. The annual variation in flock size is given in Table 3. A Pearson's $r$ data analysis revealed a strong positive correlation, $r(5)=0.79, P=0.03$, with the annual mean flock size $(M=7.6, S D=1.8, n=7)$ and annual kite count $(M=5597.7$, $S D=2739.2, n=7)$.

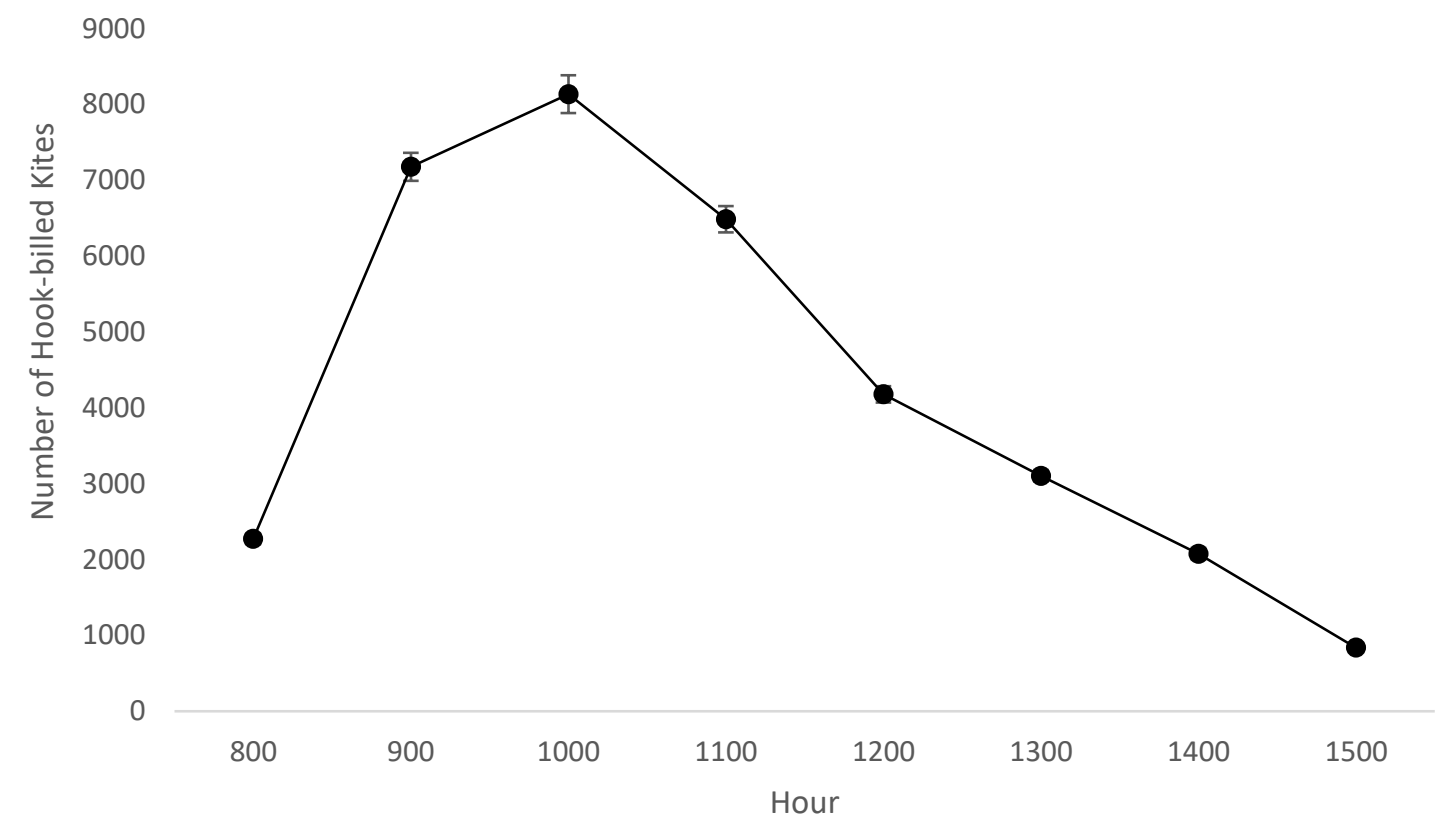

Figure 3. Daily passage activity times of the Hook-billed Kites during fall migration at the Belize migration monitoring site from 2014-2020 (7 yr, $n=34271$ kites). 


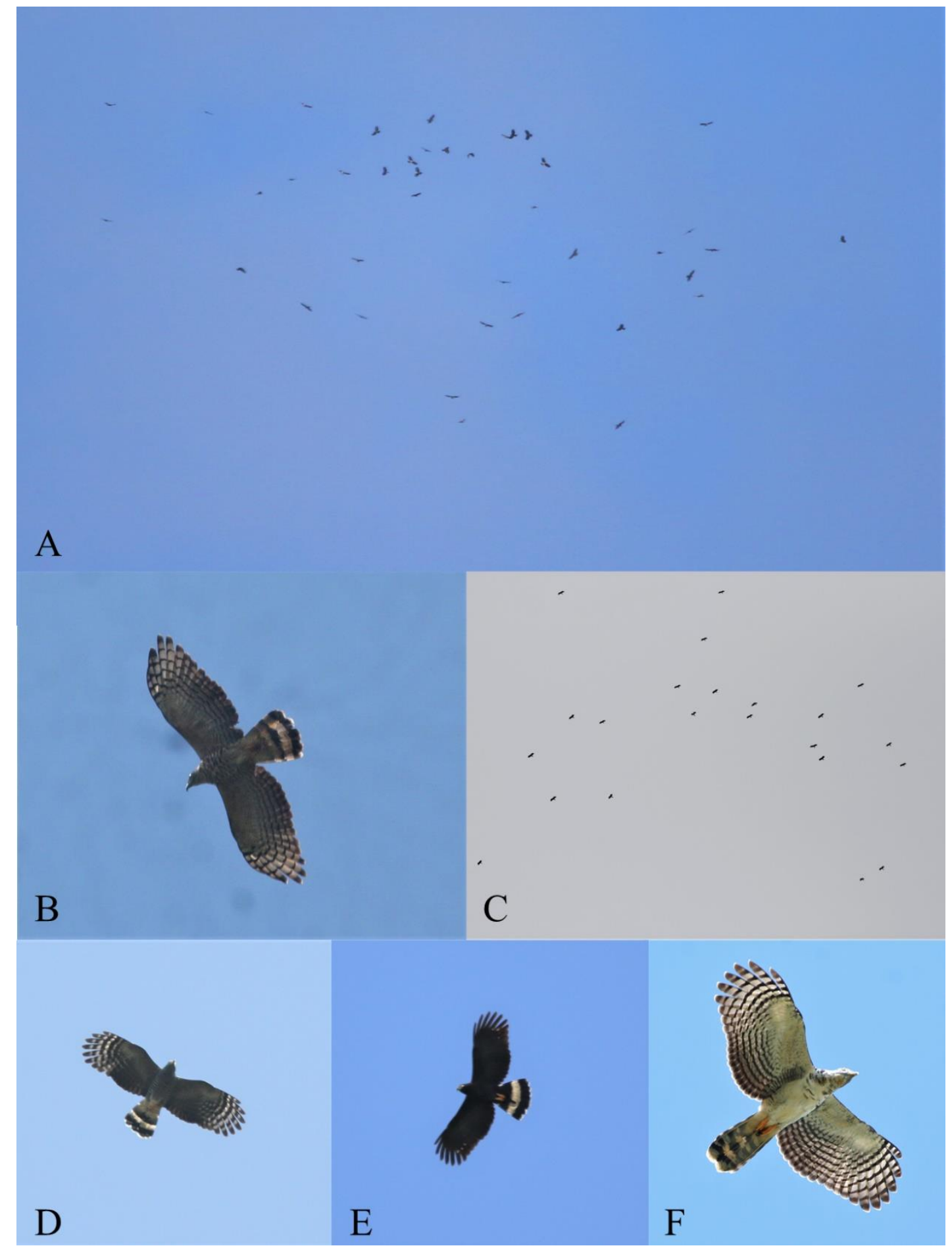

Figure 4. Southbound migrating Hook-billed Kites in Belize. (A) A large kettle on 11 November 2018. (B) Adult light morph female. (C) A flock streaming in a southern direction over count site. (D) Adult light morph male. (E) Adult dark morph. (F) Juvenile light morph. 
Table 3. Annual Hook-billed Kite flock size and number of southbound migrating flocks observed at the Belize migration monitoring site in Cattle Landing, Toledo District from 2014-2020 (7 years).

\begin{tabular}{llll}
\hline YEAR & FLOCK SIZE RANGE & MEAN \pm SE & N \\
\hline 2014 & $1-80$ & $5.3 \pm 0.3$ & 575 \\
2015 & $1-45$ & $5.7 \pm 0.3$ & 374 \\
2016 & $1-55$ & $6.7 \pm 0.3$ & 548 \\
2017 & $1-59$ & $7.4 \pm 0.3$ & 476 \\
2018 & $1-150$ & $8.1 \pm 0.5$ & 994 \\
2019 & $1-136$ & $9.7 \pm 0.5$ & 711 \\
2020 & $1-217$ & $10.0 \pm 0.6$ & 812 \\
Mean & $1-106$ & $7.6 \pm 0.4$ & 4490 \\
& & & \\
\hline
\end{tabular}

Of the 34098 Hook-billed Kites counted in Belize from 2015-2020 ( $n=6 \mathrm{yr}$ ), 24.2\% (8264 individuals) were identified to sex and 40.3\% (13723 individuals) were identified to age (juvenile or adult; Fig. 4F). The years 2013 and 2014 were excluded from this analysis because Hook-billed Kite age-sex class data was not collected in 2013, only counts, and in 2014 age-sex class data was collected for only a portion of the season. Of those individuals identified to age, adults represented $70.1 \%$ of the migratory individuals. Of the 8264 migratory kites identified to sex there was a near even sex ratio $(54.1 \%$ females and 45.9\% males; Figs. 4B and 4D). There was no differential migration of Hook-billed Kites observed, as age and sex classes migrated in mixed flocks during the entire migration season (Fig. 5). 


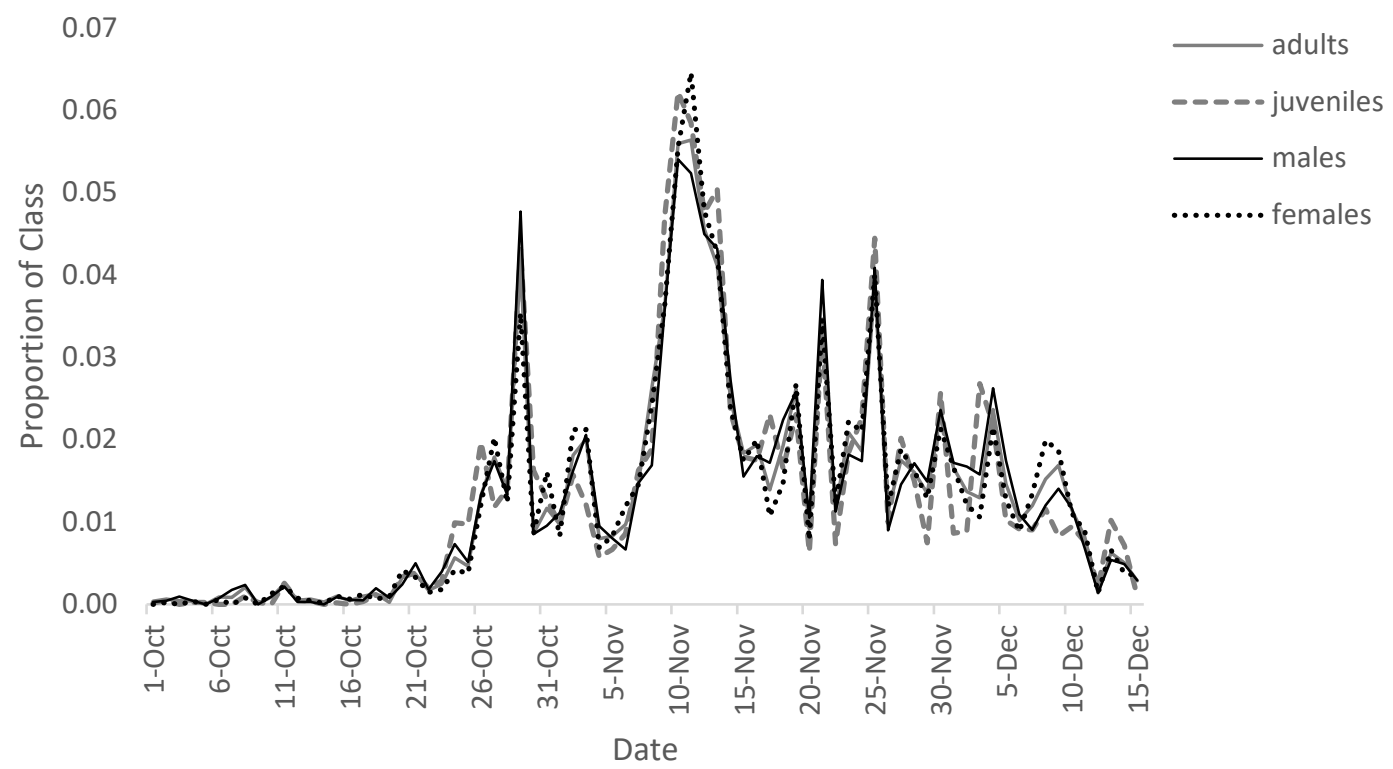

Figure 5. Comparison of the timing (mean; $n=6 \mathrm{yr}$ ) and proportions (individuals of class/total individuals of all class identified) of age and sex classes by migratory Hookbilled Kites in Belize from 2015-2020.

The mean $( \pm \mathrm{SE})$ percentage of dark morph Hook-billed Kites (Fig. 4E) in the migratory population in Belize from 2014-2020 that were identified to morph was $13.6 \%$ \pm 0.7 ( $n=16061)$. The percentage of individuals identified to morph each year ranged from 25.1 to $81.8 \%$ with a mean of $53.9 \% \pm 9.4$. The annual morph numbers can be seen in Table 4. 
Table 4. The proportion of morph type of migratory Hook-billed Kites and the total number of kites identified to morph and counted in Belize from 2014-2020.

\begin{tabular}{lcccccc}
\hline YEAR & DARK LIGHT & TOTAL ID & TOTAL COUNTED & \% DARK & $\%$ ID \\
\hline & & & & & & \\
2014 & 261 & 1666 & 1927 & 3047 & 13.5 & 63.2 \\
2015 & 185 & 1343 & 1528 & 2119 & 12.1 & 72.1 \\
2016 & 353 & 2641 & 2994 & 3661 & 11.8 & 81.8 \\
2017 & 440 & 2304 & 2744 & 3616 & 16.0 & 75.9 \\
2018 & 303 & 1994 & 2297 & 8047 & 13.2 & 28.5 \\
2019 & 261 & 1860 & 2121 & 6901 & 12.3 & 30.7 \\
2020 & 398 & 2052 & 2450 & 9755 & 16.2 & 25.1 \\
Mean & 314.4 & 1980.0 & 2294.4 & 5306.6 & 13.6 & 53.9 \\
SE & 33.4 & 159.3 & 187.0 & 1098.4 & 0.7 & 9.4 \\
\hline
\end{tabular}

'Dark', total number of dark morph kites counted; 'light', total number of light morph kites counted; 'total ID', the total number of kites identified to morph; 'total counted', the total number of kites counted for the season; ' $\%$ dark', the proportion of dark morphs counted at the Belize count site; ' $\%$ ID', the proportion of kites counted that were identified to morph.

\section{Mexico Migration}

The Hook-billed southbound autumn migration in Veracruz, Mexico was much smaller in magnitude (number of kites; Table 5) and was earlier (Fig. 6) compared to Belize. During a total of 42531 hourly counts from 1995-2019 (25 yr) at the Chichicaxtle and Cardel count sites, 3870 Hook-billed Kites were counted from 20 August-20

November, which was a rate of $0.09 \mathrm{kites} / \mathrm{hr}$. The mean $( \pm \mathrm{SE})$ annual count of migrating Hook-billed Kites in Mexico (two sites pooled) was 154.8 kites/yr $\pm 12.1(n=25)$. The highest annual count was 299 kites in 2000 during $1699.8 \mathrm{hr}$, equating to $0.18 \mathrm{kites} / \mathrm{hr}$ and the lowest annual count was 27 in 2013, a rate of $0.02 \mathrm{kites} / \mathrm{hr}$. Interestingly, the two lowest counts in Mexico and Belize occurred in 2013 (Mexico:27, Belize:744). There 
was no significant trend in migratory kite numbers at the Mexico count sites from 1995$2019\left(F_{1,23}=1.35, r^{2}=0.06, P=0.26\right.$; Fig. 7$)$ compared to an increasing trend in Belize (Fig. 2). The highest single day count over the 25 years in Mexico was 51 individuals on 18 October 2001. The high count for the Cardel site was 35 individuals on 28 September 2000 and the Chichicaxtle site was 23 individuals on 18 October 2001. The mean peak day was 14 October $(n=25)$ with a mean of $6.6 \pm 0.9$ kites (Fig. 6$)$.

Table 5. Comparison of Hook-billed Kite autumn migration totals for Belize and Mexico count sites during overlapping years (2013-2020).

\begin{tabular}{llllllllll}
\hline COUNT SITE & 2013 & 2014 & 2015 & 2016 & 2017 & 2018 & 2019 & 2020 & MEAN \pm SE \\
\hline Toledo, Belize & 744 & 5086 & 2119 & 3661 & 3616 & 8047 & 6900 & 9755 & $4991 \pm 1083$ \\
Cardel, Mexico & 11 & 88 & 82 & 41 & 32 & 68 & 64 & - & $55.1 \pm 10.6$ \\
$\begin{array}{l}\text { Chichicaxtle, } \\
\text { Mexico }\end{array}$ & 16 & 94 & 71 & 83 & 89 & 101 & 39 & 68 & $70.1 \pm 9.6$ \\
Mexico Pooled & 27 & 182 & 153 & 124 & 121 & 169 & 103 & - & $125.6 \pm 19.6$ \\
\hline
\end{tabular}




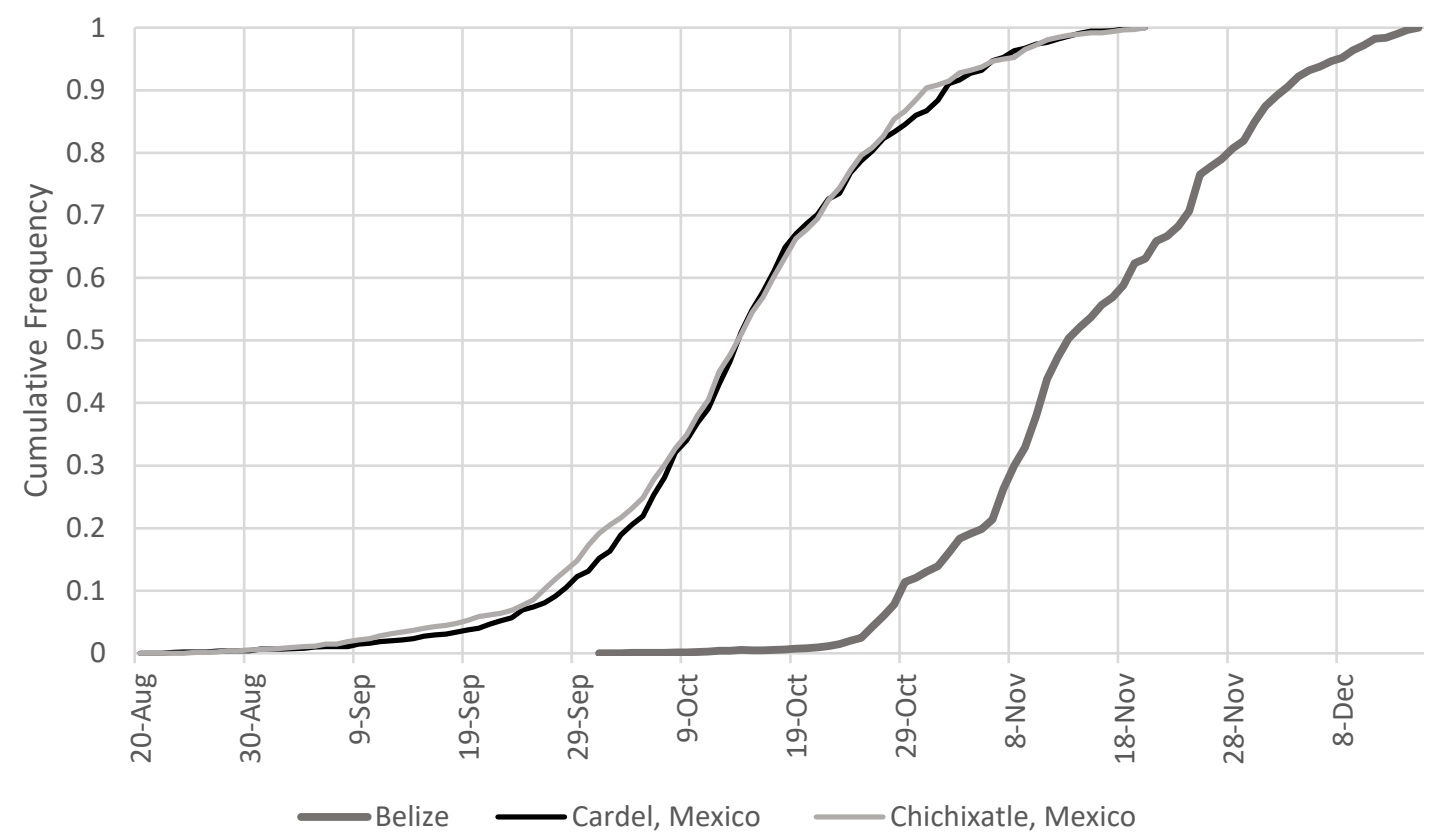

Figure 6. Comparing the Hook-billed Kite timing (day of year) of the southbound migration in Belize (2013-2020) and Mexico (1995-2019).

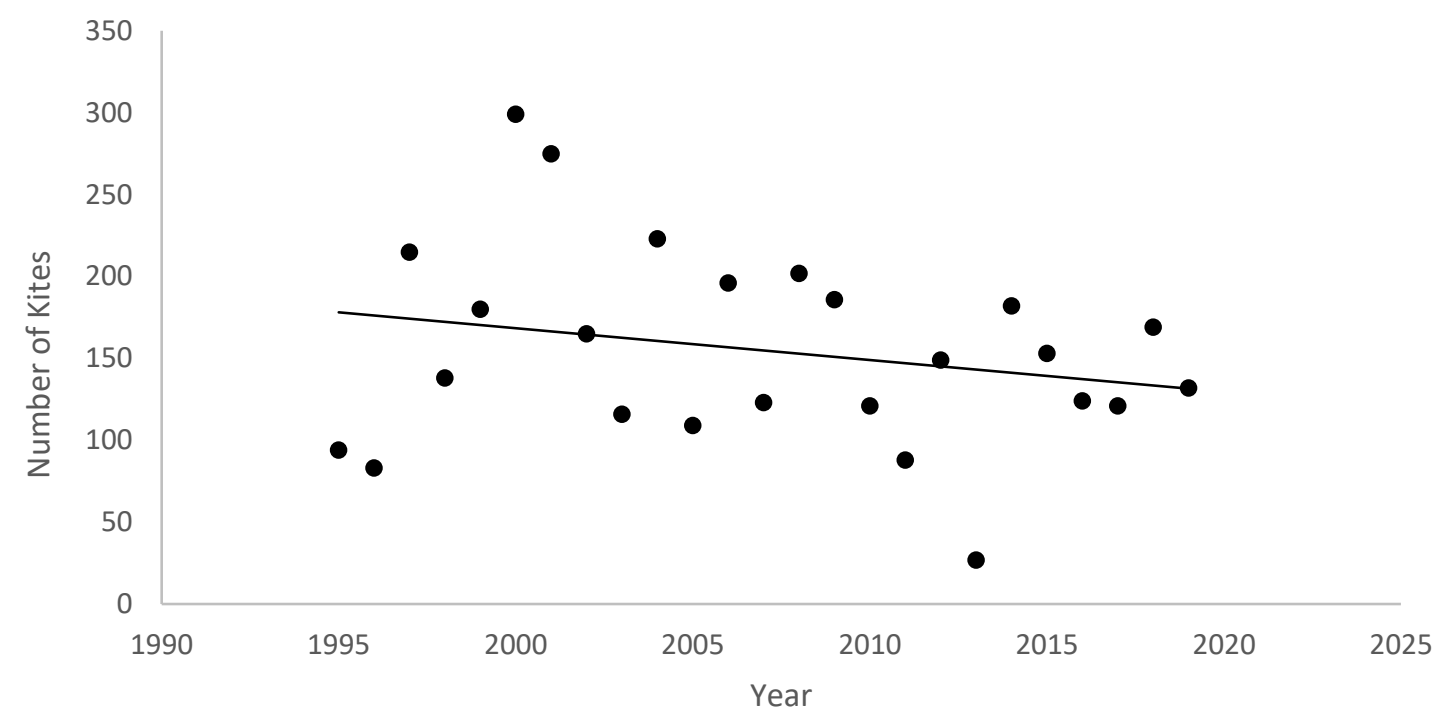

Figure 7. Population trend from 1995-2019 (25 yr) of the Mexico Hook-billed Kite fall migration. Pooled counts from the two Mexico count sites. 
The mean $95 \%$ seasonal passage window of Hook-billed Kites that passed over the Mexico count sites was from 13 September to 11 November $(29 \mathrm{~d}, n=25)$ and the mean $50 \%$ passage (median) was 14 October $(n=25)$, which was the same day as the peak day. The earliest migrating Hook-billed Kite was recorded on 23 August and the latest on 20 November.

\section{Influence of Weather}

Precipitation had no effect on the magnitude (kites/hr) of kites passing over the count site in Belize on their post-breeding migration. Of the 17 a priori candidate models for precipitation influencing kite numbers, the top model was the null model ( $W_{\mathrm{i}}=0.36$; Table

6). The only other model that was below the acceptable $<2 \Delta \mathrm{AIC}_{\mathrm{c}}$ was the annual precipitation in the Gulf Plain in eastern Mexico $\left(\Delta \mathrm{AIC}_{\mathrm{c}}=1.54, W_{\mathrm{i}}=0.17\right)$. There was no effect of precipitation on the timing of Hook-billed Kite migration south over the Belize count site when evaluating 17 a priori candidate models that included precipitation in the region and various periods prior to migration. The null model was the top model and was the only model below the acceptable $<2 \Delta \mathrm{AIC}_{\mathrm{c}}$ threshold $\left(W_{\mathrm{i}}=0.56\right.$; Table 7$)$.

In Mexico, precipitation and temperature did not influence the number of migrating Hook-billed Kites in Mexico as the top model was the null model $\left(W_{\mathrm{i}}=0.19\right)$. Four other models were below the acceptable $<2 \Delta \mathrm{AIC}_{\mathrm{c}}$ threshold (Table 8) and the top 5 models explained $65 \%$ of the variation. With respect to the timing of Hook-billed Kite migration in Mexico, two models explained $88 \%$ of the variation and were below the $<2 \Delta \mathrm{AIC}_{\mathrm{c}}$ threshold (Table 9). The top model was the total annual precipitation of the count year north of the count-site (north Gulf Coast Plain; $W_{\mathrm{i}}=0.53$; Table 9). The second model, and 
the only other accepted model that influenced the timing in Mexico was cumulative annual temperature and cumulative annual rainfall $\left(W_{\mathrm{i}}=0.35\right)$. As annual precipitation north of the Mexico count site increased the median Julian day of Hook-billed Kite migration in Mexico increased $\left(\mathrm{R}^{2}=0.33, P=0.003\right)$.

Table 6. Model selection evaluating the effects of precipitation on the breeding grounds north of the Belize count site on the number of Hook-billed Kites that migrate south during fall migration during various time periods (annual total rainfall, breeding season total rainfall, prior month total rainfall and prior year total rainfall) and geographic locations (Mexico Gulf Plain, Yucatán Peninsula, and Guatemala and Belize) from 20132019. The response variable is the number of kites per hour in a count season.

\begin{tabular}{llllll}
\hline Statistical Model & $\mathrm{k}$ & $\mathrm{AIC}_{\mathrm{c}}$ & $\Delta \mathrm{AIC}_{\mathrm{c}}$ & $W_{\mathrm{i}}$ & LogLik \\
\hline & & & & & \\
Null & 2 & 48.2 & 0.00 & 0.36 & -20.588 \\
Annual Gulf Plain & 3 & 49.7 & 1.54 & 0.17 & -17.859 \\
Prior Month Yucatán & 3 & 51.3 & 3.10 & 0.08 & -18.637 \\
Breeding Gulf Plain & 3 & 51.9 & 3.69 & 0.06 & -18.933 \\
Annual All Regions & 3 & 52.3 & 4.09 & 0.05 & -19.135 \\
Prior Month All Regions & 3 & 52.6 & 4.39 & 0.04 & -19.284 \\
Breeding Guatemala/Belize & 3 & 52.7 & 4.50 & 0.04 & -19.337 \\
Annual Guatemala/Belize & 3 & 52.8 & 4.58 & 0.04 & -19.380 \\
Breeding All Regions & 3 & 52.8 & 4.61 & 0.04 & -19.393 \\
Prior Month Gulf Plain & 3 & 52.8 & 4.64 & 0.04 & -19.408 \\
Prior Month Guatemala/Belize & 3 & 53.5 & 5.37 & 0.03 & -19.774 \\
Breeding Yucatán & 3 & 53.8 & 5.60 & 0.02 & -19.885 \\
Annual Yucatán & 3 & 54.6 & 6.40 & 0.02 & -20.287 \\
Prior Year Guatemala/Belize & 3 & 55.0 & 6.84 & 0.01 & -20.506 \\
Prior Year Yucatán & 3 & 55.1 & 6.89 & 0.01 & -20.533 \\
Prior Year Gulf Plain & 3 & 55.1 & 6.96 & 0.01 & -20.570 \\
Prior Year All Regions & 3 & 55.2 & 6.98 & 0.01 & -20.579 \\
\hline
\end{tabular}


Table 7. Model selection evaluating the effects of precipitation on the breeding grounds north of the Belize count site on the timing of Hook-billed Kites that migrate south during fall migration during various time periods (annual total rainfall, breeding season total rainfall, prior month total rainfall and prior year total rainfall) and geographic locations (Mexico Gulf Plain, Yucatán Peninsula, and Guatemala and Belize) from 20132019. The response variable is the Julian day of the median passage (50\%) in a count season.

\begin{tabular}{llllll}
\hline & & & & & \\
Statistical Model & $\mathrm{k}$ & $\mathrm{AIC}_{\mathrm{c}}$ & & & \\
& & & & & \\
& & & & & \\
& & 52.4 & 0.00 & 0.56 & -22.702 \\
Null & 3 & 57.3 & 4.91 & 0.05 & -21.656 \\
Annual Gulf Plain & 3 & 57.5 & 5.07 & 0.05 & -21.737 \\
Prior Month Yucatán & 3 & 57.6 & 5.24 & 0.04 & -21.822 \\
Annual Guatemala/Belize & 3 & 58.2 & 5.76 & 0.03 & -22.081 \\
Prior Year Guatemala/Belize & 3 & 58.3 & 5.88 & 0.03 & -22.143 \\
Breeding Guatemala/Belize & 3 & 58.3 & 5.89 & 0.03 & -22.146 \\
Prior Month Guatemala/Belize & 3 & 58.5 & 6.08 & 0.03 & -22.243 \\
Prior Month All Regions & 3 & 58.6 & 6.24 & 0.03 & -22.323 \\
Annual All Regions & 3 & 58.7 & 6.31 & 0.02 & -22.357 \\
Breeding All Regions & 3 & 58.8 & 6.43 & 0.02 & -22.415 \\
Prior Month Gulf Plain & 3 & 58.9 & 6.51 & 0.02 & -22.456 \\
Breeding Gulf Plain & 3 & 59.0 & 6.58 & 0.02 & -22.493 \\
Prior Year All Regions & 3 & 59.2 & 6.78 & 0.02 & -22.592 \\
Breeding Yucatán & 3 & 59.3 & 6.87 & 0.02 & -22.637 \\
Prior Year Gulf Plain & 3 & 59.4 & 6.96 & 0.02 & -22.683 \\
Prior Year Yucatán & 3 & 59.4 & 7.00 & 0.02 & -22.701 \\
Annual Yucatán & & & & &
\end{tabular}

Table 8. Model selection evaluating the effects of precipitation and temperature on the breeding grounds north of the Mexico count sites on the number of Hook-billed Kites that migrate south during fall migration during various time periods (annual: JanuaryDecember, breeding season: May-August, prior month: August, and prior year (JanuaryDecember) from 1995-2019. The response variable is the number of kites per hour in a count season.

\begin{tabular}{lccccc}
\hline Statistical Model & $\mathrm{k}$ & $\mathrm{AIC}_{\mathrm{c}}$ & $\Delta \mathrm{AIC}_{\mathrm{c}}$ & $W_{\mathrm{i}}$ & LogLik \\
\hline & & & & & \\
Null & 2 & -91.7 & 0.00 & .19 & 48.111 \\
Breeding Precip & 3 & -91.2 & 0.45 & .15 & 49.186 \\
Annual Temp & 3 & -90.8 & 0.90 & .12 & 48.959 \\
Prior Month Precip & 3 & -90.5 & 1.18 & .11 & 48.818 \\
Annual Precip & 3 & -89.8 & 1.87 & .08 & 48.474
\end{tabular}


Prior Month Temp

Annual Precip + Annual Temp

$\begin{array}{llll}3 & -89.3 & 2.34 & .06\end{array}$

.06

48.237

Prior Year Precip

$\begin{array}{lll}4 & -89.2 & 2.50\end{array}$

49.590

Prior Year Temp

$-89.2 \quad 2.51$

48.156

Breeding Temp

$\begin{array}{llll}3 & -89.1 & 2.55 & .05\end{array}$

.05

Breeding Precip + Breeding Temp

$\begin{array}{ll}-89.1 & 2.59 \\ -88.7 & 2.97\end{array}$

48.135

$\begin{array}{ll}-88.7 & 2.97\end{array}$

48.112

Prior Month Precip + Prior Month Temp

Prior Year Precip + Prior Year Temp

$\begin{array}{lll}4 & -88.7 & 2.97 \\ 4 & -87.7 & 4.00\end{array}$

.05

49.354

$-86.3 \quad 5.34$

48.836

48.169

Table 9. Model selection evaluating the effects of precipitation and temperature on the breeding grounds north of the Mexico count sites on the timing of Hook-billed Kites that migrate south during fall migration during various time periods (annual: JanuaryDecember, breeding season: May-August, prior month: August, and prior year (JanuaryDecember) from 1995-2019. The response variable is the Julian day of the median passage $(50 \%)$ in a count season.

\begin{tabular}{|c|c|c|c|c|c|}
\hline Statistical Model & $\mathrm{k}$ & $\mathrm{AIC}_{\mathrm{c}}$ & $\Delta \mathrm{AIC}_{\mathrm{c}}$ & $W_{\mathrm{i}}$ & LogLik \\
\hline Annual Precip & 3 & 136.3 & 0.00 & .53 & -64.585 \\
\hline Annual Precip +Annual Temp & 4 & 137.1 & 0.83 & .35 & -63.570 \\
\hline Prior Year Precip & 3 & 141.2 & 4.92 & .05 & -67.044 \\
\hline Breeding Precip + Breeding Temp & 4 & 142.8 & 6.51 & .02 & -66.412 \\
\hline Prior Year Precip + Prior Year Temp & 4 & 143.7 & 7.41 & .01 & -66.863 \\
\hline Null & 2 & 143.8 & 7.54 & .01 & -69.652 \\
\hline Breeding Precip & 3 & 144.1 & 7.79 & .01 & -68.479 \\
\hline Breeding Temp & 3 & 145.2 & 8.85 & .01 & -69.008 \\
\hline Prior Month Temp & 3 & 145.5 & 9.14 & .01 & -69.155 \\
\hline Annual Temp & 3 & 146.0 & 9.71 & .00 & -69.440 \\
\hline Prior Month Precip & 3 & 146.4 & 10.06 & .00 & -69.613 \\
\hline Prior Year Temp & 3 & 146.4 & 10.13 & .00 & -69.650 \\
\hline Prior Month Precip and Prior Month Temp & 4 & 148.2 & 11.88 & .00 & -69.098 \\
\hline
\end{tabular}




\section{DISCUSSION}

The present research represented the first description and long-term study of the Hook-billed Kite migration in Belize and Mexico. Overall, I found that the migration through Belize was the largest documented migration of the species. With an annual average of approximately 5000 Hook-billed Kites migrating through Belize and nearly 10000 counted in 2020 , Belize is the most important concentration point and putatively a migratory corridor for this Neotropical raptor.

While Veracruz, Mexico has the largest concentration of migratory raptors at any one site in the world (Ruelas 2005), my results indicate that a higher proportion of Hookbilled Kites migrate through Belize An average of 154 Hook-billed Kites were counted annually at the two Veracruz sites combined, which was only $3.1 \%$ bird counts observed in Belize. These differences are not unexpected for several reasons. First, these count sites are north of the Belize count site and nearer the northern extent of the species' range. Thus, there is likely fewer breeding birds to pass by given the smaller breeding area compared to the Belize site. Second, we expect that Hook-billed Kites counted in Mexico could be passing through Belize as the median date in Mexico is nearly a month earlier than passage in Belize (14 October versus 11 November, respectively), thereby adding to the Belize numbers. The distance between the Mexico and Belize sites is $c$. $1000 \mathrm{~km}$. Capitolo et al. (2020) tracked migrating Broad-winged Hawks, where daily straight-line migration distances were between 110-265 km. If it takes Hook-billed Kites approximately the same duration to migrate, then kites in Mexico would reach Belize in 4-10 d, the estimated lag time between sites based on distance. It is plausible that the 
Mexico Hook-billed Kites are moving through Belize and are counted at all migration monitoring sites. However, given the much greater numbers of kites passing through Belize, it seems like most of this migratory population breeds in the southern Gulf Coast Plain and Yucatán Peninsula, between Veracruz and the Belize count sites.

Hook-billed Kites that migrate through Belize spend the non-breeding season at an unknown location. Flocks of migratory Hook-billed Kites are not observed in any other Central American countries south of Belize (Porras-Penaranda et al. 2004, McCrary and Young 2008, Tenorio et al. 2020). Tenorio et al. (2020) observed migrating Hook-billed Kites for the first time in Costa Rica in 2018; however, it was on 8 September, which is too early to be the Belize kites and appear to be locally migratory individuals.

Jones (2002) estimated that 5000 Hook-billed Kites migrate each year through Belize and concluded that the species is the most common autumn raptor migrant in Belize. My results support this conclusion. However, systematic annual migration counts show that there is an extreme variation between years as there was a range of 744 to 9755 kites at the Belize count site. Every year Hook-billed Kites migrated at relatively the same time both in Belize and Mexico, suggesting that there is a local population in the northern extent of their range that have regular annual migratory movements. Whether Hookbilled Kites exhibit facultative or obligate migration is unknown. However, most obligate migratory raptor species in both tropical and boreal regions exhibit a differential migration where age and sex classes differ in the timing of migration (Kjellén 1992, Hull et al. 2012, Goodrich and Smith 2008, Vansteelant et al. 2020). In Belize, there was no difference in timing between age and sex classes, which is evidence in the direction that 
this species in this region is a facultative or irruptive migrant. Therefore, categorizing the Hook-billed Kite as a facultative migrant, local migrant, and resident species are all accurate and these migratory distinctions may vary at the local population level as occurs in many species (Chapman et al. 2011).

However, the factors that trigger the Hook-billed Kite migration are unknown. My examination of precipitation did not appear to influence whether Hook-billed Kites choose to migrate or not, but it has been documented that local drought events cause abandonment of those areas leading to a local decline or extirpation (T. Brush pers. comm.). The dynamics of what influences the movement of Hook-billed Kites requires further investigation.

In Mexico and Belize, habitat loss may be influencing Hook-billed Kite migration to a greater extent than weather. Over the past $20 \mathrm{yr}$ in Mexico, within the breeding range of Hook-billed Kites, deforestation has exponentially increased with an estimated 150000 ha of forest cleared annually (Ellis et al. 2017). Most of the recent deforestation is occurring in the Yucatán Peninsula, which is the largest area with suitable breeding habitat for Hook-billed Kites and likely the breeding grounds for many or most of the kites migrating through Belize (Ellis et al. 2017). With continued forest loss and fragmentation, land snails, and more specifically arboreal snails (the main prey of Hookbilled Kites; Phillips et al. in review), are a highly vulnerable taxonomic group with limited mobility and high sensitivity to environmental changes (Forys et al. 2001, Dourson pers. comm, Breure pers comm.). Even if fragmented forest patches remain, the isolated snails may be more vulnerable to predation, disease, invasive species, and lack of 
gene flow which can cause declines and extinction (Dourson pers. comm.). A decline in arboreal snails in heavily deforested areas will have deleterious impacts on Hook-billed Kite populations as individuals rely on thousands of snails throughout the year and especially for reproduction (Phillips et al. in review).

While increasing numbers of Hook-billed Kites migrating through Belize could indicate a growing breeding population, this pattern many also be a migratory response to increased loss of habitat and prey on their breeding grounds in Mexico. Predators respond to changes in prey abundance in two ways, functionally by switching prey base or numerically by moving (Redpath and Thirgood 1999). Specialist species, such as the Hook-billed Kite, may respond numerically by moving because they may not be able to adapt quick enough by changing their prey base (Andersson and Erlinge 1977, Redpath and Thirgood 1999). As habitat is lost, fewer birds may be able to remain year-round resulting in larger migration numbers. Furthermore, this migration is a relatively recently ( $<25 \mathrm{yr}$ ) observed phenomena that could be due to fewer or no Hook-billed Kites migrating from their breeding grounds because there was previously more habitat and snails to sustain the kites. However, it could also be a result of more observers in the field, but it seems like these large conspicuous flocks would have been observed. With a dramatic increase in forest loss and fragmentation they may be forced to move to find resources during the non-breeding season. The exceptionally large number of migrants and the increasing trend of migrants could be a result of forest loss and a response to decreased prey availability, which may highlight a serious conservation concern for this species. 
The Hook-billed Kite is a unique species that affords an excellent opportunity to study a specialized Neotropical raptor. Because of the tight predator-prey relationship between this raptor and land snails, Hook-billed Kites could be an important indicator of the threats to Neotropical ecosystems and changes in Neotropical community dynamics. Future research priorities should be focused on better understanding if this is truly an irruptive migration by tracking the movement of kites over multiple years to determine where they are spending their non-breeding months. Other important research questions include whether Hook-billed Kites return to the same nesting sites, if migration distance varies each year, and if the same individuals migrate every year. Understanding the nonbreeding areas, habitat requirements, and the movement dynamics of this significant population of migratory Hook-billed Kites is important and could focus conservation and land protection efforts. Importantly, understanding Neotropical land snail ecology and their response to habitat fragmentation will also assist in deciphering the complex ecology of Hook-billed Kites and help determine if human caused habitat loss is a driving force in the recent increase in migratory numbers, as well as what role the threats from climate change contribute. 


\section{LITERATURE CITED}

Abatzoglou, J. T., S. Z. Dobrowski, S. A. Parks, and K. C. Hegewisch. (2018).

TerraClimate, a high-resolution global dataset of monthly climate and climatic water balance from 1958-2015. Scientific Data 5:170191. https://doi.org/10.1038/sdata.2017.191.

Akaike, H. (1973). Information theory and an extension of the maximum likelihood principle. In: Second International Symposium of Information Theory (B. N. Petrov and B. F. Csaki, Eds.) Budapest: Acadamei Kiado. pp. 267-281.

Albuquerque, F. S, M. C. Peso-Aguiar, M. J. T. Assuncão-Albuquerque, and L. Galvez. (2009). Do climate variables and human density affect Achatina fulica (Bowditch) (Gastropoda: Pulmonata) shell length, total weight and condition factor? Brazil Journal of Biology 69:879-885.

Anderson, D. R., and K. P. Burnham. (2002). Avoiding pitfalls when using informationtheoretic methods. Journal of Wildlife Management 66:912-918.

Andersson, M., and S. Erlinge. (1977). Influence of predation on rodent populations. Oikos 29:591-597.

Barrientos, Z. (2000). Population dynamics and spatial distribution of the terrestrial snail Ovachlamys fulgens (Stylommatophora: Helicarionidae) in a tropical environment. Revista de Biologia Tropical 48:71-87.

Bartoń, K. (2019). MuMIn: Multi-modal inference. Version 1.43.6. CRAN - Package MuMIn (r-project.org).

Bildstein, K. L. (2004). Raptor migration in the Neotropics: Patterns, process, and consequences. Ornitol. Neotrop. 15:83-99.

Bildstein, K. L. (2006). Migrating raptors of the world: their ecology and conservation. Cornell University Press, Ithaca, NY, USA.

Bildstein, K. L., J. P. Smith, and R. Yosef. (2007). Migration counts and monitoring. In Raptor Research and Management Techniques (D. M. Bird and K. L. Bildstein, Editors). Hancock House Publishers, Blaine, WA, USA. pp. 101-116.

BirdLife International (2020). Chondrohierax uncinatus. IUCN Red List of Threatened Species 2020: e.T22694971A168997614. https://dx.doi.org/10.2305/IUCN.UK.20203.RLTS.T22694971A168997614.en. 
Boyle, W. A. (2011). Short-distance partial migration of Neotropical birds: a communitylevel test of the foraging limitation hypothesis. Oikos 120:1803-1816.

Brush, T. (2005). Nesting birds of the tropical frontier: the Lower Rio Grande Valley of Texas. Texas A \& M University Press, College Station, TX, USA.

Buechley, E. R., A. Santangeli, M. Girardello, M. H. Neate-Clegg, D. Oleyar, C. J. McClure, and C. H. Şekercioğlu. (2019). Global raptor research and conservation priorities: Tropical raptors fall prey to knowledge gaps. Diversity and Distributions 25(6):856-869.

Burnham, K. P., and D. R. Anderson. (2002). Model selection and multi-modal Inference: A Practical Information -Theoretic Approach. Second Edition. Springer-Verlag, New York, NY, USA.

Burnham, K. P., D. R. Anderson, and K. P. Huyvaert. (2011). AIC model selection and multimodal inference in behavioral ecology: some background, observations, and comparisons. Behavioral Ecology and Sociobiology 65:23-35.

Capitolo, P. J., L. J. Jesus, A. B. Harper, A. M. Fish, and A. C. Hull. (2020). Fall migration of radio-tagged Broad-winged Hawks (Buteo platypterus) in California. The Wilson Journal of Ornithology 132(1):15-21.

Carrete, M., J. L. Tella, G. Blanco, and M. Bertellotti. (2009). Effects of habitat degradation on the abundance, richness and diversity of raptors across Neotropical biomes. Biological Conservation 142:2002-2011.

Chapman, B. B, C. Brönmark, J.-Å. Nilsson and L-A. Hansson. 2011. The ecology and evolution of partial migration. Oikos 120:1764-1775.

Clark, W. S. (2002). First nesting of dark-morph Hook-billed Kite in the United States. North American Birds 56:260-262.

Clark, W. S. (2003). Observations on nesting Hook-billed Kites in the Rio Grande Valley. Bulletin of Texas Ornithological Society 36:40.

Clark, W. S. (2004). First dark-morph Hook-billed Kite fledged in the United States. North American Birds 58:170.

Clark, W. S., and N. J. Schmitt. (2017). Raptors of Mexico and Central America. Princeton University Press, Princeton, NJ, USA.

Colorado, G. J., M. J. Bechard, C. Marquez, and A. M. Castano. (2006). Raptor migration in the Cauca River Valley of northern Colombia. Ornitologia Neotropical 17:161-172. 
De Melo Dantas, S., C. E. B. Portes, E. Pinheiro, and G. M. Kirwan. (2018). A review of flocking behavior by Hook-billed Kite, Chondrohierax uncinatus, in South America. Revista Brasileira de Ornitologia 26(1):9-11.

Delnicki, D. (1978). Second occurrence and first successful nesting record of the Hookbilled Kite in the United States. The Auk 95(2):427-427.

DeSimone, J. G., B. W. Tobalske, and C. W. Breuner. (2021). Physiology and behavior under food limitation support an escape, not preparative, response in the nomadic pine siski (Spinus pinus). Journal of Experimental Biology 224, jeb238774. doi: $10.1242 / \mathrm{jeb} .238774$.

Dingle, H. (2014). Migration: The Biology of Life on the Move, Ed. 2. Oxford University Press, New York, USA.

Di Giacomo, A. G. (2000). Nesting of some little-known raptors in the Eastern Chaco of Argentina. El Hornero 15(2):135-139.

Dunkadoo. (2021, February 23). Dunkadoo about. Retrieved from https://dunkadoo.org/about.

Ellis, E. A., J. A. R. Montero, I. U. H. Gómez, L. Porter-Bolland, and P. W. Ellis. (2017). Private property and Mennonites are drivers of forest cover loss in Central Yucatán Peninsula, Mexico. Land Use Policy 69:474-484.

Estes, J.A., J. Terborgh, J. S. Brashares, M. E. Power, J. Berger, W. J. Bond, S. R. Carpenter, T. E. Essington, R. D. Holt, J. B. C. Jackson, R. J. Marquis, L. Oksanen, T. Okansen, R. T. Paine, E. K. Pikitch, W. J. Ripple, S. A. Sandin, M. Scheffer, T. W. Schoener, J. B. Shurin, A. R. E. Sinclair, M. E. Soule, R. Virtanen, and D. A. Wardle. (2011). Trophic downgrading of Planet Earth. Science 333:301-306.

Farmer, C. J., and J. P. Smith. (2010). Seasonal differences in migration counts of raptors: utility of spring counts for population monitoring. Journal of Raptor Research 44(2):101-112.

Ferguson-Lees, J., and D. A. Christie. (2001). Raptors of the world. Houghton Mifflin, New York, NY, USA.

Fish, A. M. (1995). How to measure a hawk migration-evolution of the quadrant system at the Golden Gate (Abstract). Journal of Raptor Research 29:56.

Fish, A. M. (2001). More than one way to count a hawk: toward site-specific documentation of raptor-migration count field methods. In Hawkwatching in the 
Americas (K.L. Bildstein and D. Klem, Jr., Editors). Hawk Migration Association of North America, North Wales, PA, USA. pp. 161-168.

Fleetwood, R. J., and J. L. Hamilton. (1967). Occurrence and nesting of the Hook-billed Kite (Chondrohierax uncinatus) in Texas. The Auk 84(4):598-601.

Forys, E. A., A. Quistorff, C. R. Allen, and D. P. Wojcik. (2001). The likely cause of extinction of the tree snail Orthalicus reses reses (Say). J. Moll. Stud. 67:369-376.

Goodrich, L. J., and J. P. Smith. (2008). Raptor migration in North America. In State of North America's Birds of Prey Series in Ornithology No. 3. (K. L. Bildstein, J. P. Smith, E. I. Ruelas, and R. R. Veit, Editors). Nuttall Ornithological Club, Cambridge, MA, USA and American Ornithologist's Union, Washington, DC, USA. pp. 27-150.

Hartshorn, G. S., L. Nicolait, L. Hartshorn, G. Bevier, R. Brightman, J. Cal, A. W. Davidson, R. Dubois, C. Dyer, J. Gibson, W. Hawley, J. Leonard, R. Nicolait, D. Weyer, H. White, and C. Wright. (1984). Belize country environmental profile: a field study. USAID Contract No. 505-0000-C-00-3001-00. Robert Nicolait \& Associates Ltd., Belize City, Belize.

Haverschmidt, F. (1964). Investigations on Chondrohierax uncinatus (Temminck) in Surinam. J. Ornithologie 105:64-66.

Haverschmidt, F. (1968). Birds of Surinam, Edinburgh: Oliver and Boyd.

Hayes, F. E. (1995). Definitions for Migrant Birds: What is a Neotropical Migrant? The Auk 112(2):521-523.

Henrique, R. S., and T. Grant. (2019). Influence of environmental factors on short-term movements of butter frogs (Leptodactylus latrans). Herpetologica 75(1):38-46.

Hoffman, S. W., and J. P. Smith. (2003). Population trends of migratory raptors in western North America, 1977-2001. The Condor 105:397-419.

Howell, S. N. G., and S. Webb. (1995). A guide to the birds of Mexico and northern Central America. Oxford University Press, New York, NY, USA.

Hull, J. M., S. Pitzer, A. M. Fish, H. B. Ernest, and A. C. Hull. (2012). Differential migration in five species of raptors in Central Coastal California. Journal of Raptor Research 46:50-56.

Johnson, J.A., R. Thorstrom, and D. P. Mindell. (2007). Systematics and conservation of the hook-billed kite including the island taxa from Cuba and Grenada. Animal Conservation 10:349-359. 
Jones, H. L. (2002). Central America. N. Amer. Birds 56:115-117.

Kjellén, N. (1992). Differential timing of autumn migration between sex and age groups in raptors at Falsterbo, Sweden. Ornis Scandinavica 23:420-434.

Kottek, M., J. Grieser, C. Beck, B. Rudolf, and F. Rubel. (2006). World map of the Köppen-Geiger climate classification updated. Meteorologische Zeitschrift 15(3):259-263.

Krügel, M. M. (2003). Registro documentado de Chondrohierax uncinatus (Temminck, 1822)(Falconiformes: Accipitridae) para o Rio Grande do Sul. Ararajuba 11(1):83-84.

Li, T., and Q. Meng. (2017). Forest dynamics to precipitation and temperature in the Gulf of Mexico coastal region. Int. J. Biometeorol 61:869-879.

Lukacs, P. M., W. L. Thompson, W. L. Kendall, W. R. Gould, P. F. Doherty Jr., K. P. Burnham, and D. R. Anderson. (2007). Concerns regarding a call for pluralism of information theory and hypothesis testing. Journal of Applied Ecology 44:456-460.

Marroquin, V. M. A., E. Reyes Moreno, and T. D. Ortiz. (1992). Nesting biology of three species of kite. Pp. 145-152 in D. Whitacre and R. Thorstrom (eds.), Maya Project Progress Report V, 1992. The Peregrine Fund, Inc., Boise, ID.

McClure, C. J. W., J. R. S. Westrip, J. A. Johnson, S. E. Schulwitz, M. Z. Virani, R. Davies, A. Symes, H. Wheatley, R. Thorstrom, A. Amar, R. Buij, V. R. Jones, N. P. Williams, E. R. Buechley, and S. H. M. Butchart (2018). State of the world's raptors: Distributions, threats, and conservation recommendations. Biological Conservation 227:390-402.

McHugh, M. L. (2012). Interrater reliability: the kappa statistic. Biochemia Medica 22(3):276-282.

Meerman, J., and W. Sabido. (2001). Central American ecosystems: Belize. Programme for Belize, Belize City, Belize.

Miller, R. A., A. Onrubia, B. Martin, G. S. Kaltenecker, J. D. Carlisle, M. J. Bechard, and M. Ferrer. (2016). Local and regional weather patterns influencing post-breeding migration counts of soaring birds at the Strait of Gibraltar, Spain. Ibis 158:106-115.

National Meteorological Service of Belize. (2021). The climate of Belize: climate summary. Retrieved from http://www.hydromet.gov.bz/climatology/climatesummary. 
Newton, I. (2006). Advances in the study of irruptive migration. Ardea 94:432-460.

Newton, I. (2008). The migration ecology of birds. Academic Press, London, UK.

Newton, I. (2012). Obligate and facultative migration in birds: ecological aspects. Journal of Ornithology 153:171-180.

Orians, G. H., and D. R. Paulson. (1969). Notes on Costa Rican birds. The Condor 71(4):426-431.

Parkes, H. B., G. R. Wiley, M. D. Berstein, H. F. Cline, E. C. Griffin, A. Palerm, and M. C. Meyer. (2021, March 5). Mexico. Encyclopedia Britannica. https://www.britannica.com/place/Mexico.

Perez, K. E., B. S. Lewis Najev, B. Christoffersen, and J. C. Nekola. (2021). Biotic homogenization or riparian refugia? Urban and wild land snail assemblages along a subtropical precipitation gradient. Journal of Urban Ecology 7(1). https://doi.org/10.1093/jue/juab002

Phillips, R. (2014). BRRI Raptorwatch Manual- $2^{\text {nd }}$ Edition. Belize Raptor Research Institute, Campbell, CA, USA.

Phillips, R. A., J. C. Meerman, T. Boomsma, R. P. Bourbour, B. L. Martinico, R. Howe, and R. Martinez. (2021). Breeding ecology of the Hook-billed Kite, Chondrohierax uncinatus, in Belize, Central America. Journal of Raptor Research (in review).

R Core Team. 2020. R: A language and environment for statistical computing (version 3.6.3). Retrieved from https://www.r-project.org/

Redpath, S. M., and S. J. Thirgood. (1999). Numerical and functional responses in generalist predators: hen harriers and peregrines on Scottish grouse moors. Journal of Animal Ecology 68:879-892.

Rhoda, R, and T. Burton. (2010). Geo-Mexico: the geography and dynamics of modern Mexico. Sombrero Books, Ladysmith, BC, Canada.

Rodríquez-Santana, F., Y. S. Vega, M. S. Padilla, C. P. León, Y. E. T. Adán, M. S. Losada, A. M. Lescay, and Y. Rivera. (2004). Magnitude and timing of autumn Osprey migration in southeastern Cuba. Journal of Raptor Research 48(4):334-344.

Rowley, J.S. (1984). Breeding records of land birds in Oaxaca, Mexico. Proc. West. Found. Vertebr. Zool. 2:73-224. 
Ruelas, I. E. (2005). Raptor and wading bird migration in Veracruz, Mexico: spatial and temporal dynamics, flight performance, and monitoring applications. Ph.D. dissertation. University of Missouri. Columbia, MO, USA.

Ruelas, I. E., L. J., Goodrich, and S. W. Hoffman. (2009). North American population estimates of waterbirds, vultures and hawks from migration counts in Veracruz, México. Bird Conservation International 20:124-133.

Ruelas, I. E., L. J. Goodrich, and S. W. Hoffman. (2010). Cambios en las poblaciónes de aves rapaces migratorias en Veracruz, Mexico, 1995-2005. Acta Zoológica Mexicana 26(3):495-525.

Seavy, N. E., M. D. Schulze, D. F. Whitacre, and M. A. Vásquez. (2012). Plumbeous Kite. In Neotropical birds of prey: biology and ecology of a raptor forest community (D. F. Whitacre, Editor). Cornell University Press, Ithaca, NY, USA. pp. 82-92.

Sergio, F., I. A. N. Newton, L. Marchesi, and P. Pedrini. (2006). Ecologically justified charisma: preservation of top predators delivers biodiversity conservation. Journal of Applied Ecology 43(6):1049-1055.

Smith, T. B. (1982). Nests and young of two rare raptors in Mexico. Biotropica 14:79-80.

Smith, T. B. (1988). Hook-billed Kite. In R. S. Palmer, ed., Handbook of North American birds, vol. 4, pp. 102-108. New Haven, CT: Yale Univ. Press.

Smith, T. B., and S. A. Temple. (1982). Grenada Hook-billed Kites: recent status and life history notes. Condor 84(1):131-131.

Stiles, F. G., and A. F. Skutch. (1989). A guide to the birds of Costa Rica. Cornell University Press, Ithaca, NY, USA.

Sullivan, B. L., C. L. Wood, M. J. Iliff, R. E. Bonney, D. Fink, and S. Kelling. (2009). eBird: a citizen-based bird observation network in the biological sciences. Biological Conservation 142:2282-2292.

Tenorio, J., V. Abarca-Fallas, and O. Ramirez-Alan. (2020). Migration of Hook-billed kite (Chondrohierax uncinatus) in Kèköldi, Costa Rica. Spizaetus 29:14-18.

Thorstrom, R., E. Massiah, and C. Hall. (2001). Nesting biology, distribution, and population estimate of the Grenada Hook-billed Kite Chondrohierax uncinatus mirus. Caribb. J. Sci. 37:278-281.

Thorstrom, R., and D. McQueen. (2008). Breeding and status of the Grenada Hook-billed kite (Chondrohierax uncinatus mirus). Ornitologia Neotropical 19:221-228. 
Vansteelant, W. M. G., J. Wehrmann, D. Engelen, J. Jansen, B. Verhelst, R. Benjumea, S. Cavailles, T. Kaasiku, B. Hoekstra, and Folkertdeboer. (2020). Accounting for differential migration strategies between age groups to monitor raptor population dynamics in the eastern Black Sea flyway. Ibis 162:356-372.

Webster, F. S., Jr. (1978). South Texas Region. American Birds 32:1183.

Whitacre, D. F. (2012). Neotropical birds of prey: biology and ecology of a raptor forest community. Cornell University Press, Ithaca, NY, USA.

Whitacre, D. F., and M. A. Vásquez. (2012). Hook-billed Kite. In Neotropical birds of prey: biology and ecology of a raptor forest community (D. F. Whitacre, Editor). Cornell University Press, Ithaca, NY, USA. pp. 48-59.

Young, C. A. (2008). Belize's ecosystems: threats and challenges to conservation in Belize. Tropical Science Conservation 1:18-30.

Zalles, J. I., and K. L. Bildstein. (2000). Raptor watch: A global directory of raptor migration sites. Cambride, UK: Birdlife International; and Kemptin, PA, USA; Hawk Mountain Sanctuary (Birdlife Conservation Series No. 9).

Zar, J. H. (1999). Biostatistical analysis. Prentice Hall Inc., Upper Saddle River, NJ, USA. 